\title{
Analisis Kritis dan Pragmatis Caring Economics sebagai Paradigma baru Kajian Ekonomi
}

\author{
Mit Witjaksono \\ Fakultas Ekonomi, Universitas Negeri Malang, Indonesia \\ E-mail:mitrojoyo@gmail.com,mit.witjaksono.fe@um.ac.id
}

Diterima: May 12, 2016; Disetujui: September 27, 2016; Dipublikasikan: November 4, 2016

Permalink/DOI: http://dx.doi.org/10.17977/um002v8i22016p217

\begin{abstract}
This article critically and pragmatically analyze and expose the concept and basic principles of caring economics as a new paradigm of economics as opposed to neo-liberal economics and its implications to economic education in Indonesia. The analysis and exposition based on unobtrusive research techniques, i.e. comparative content analysis and historical notes among references used here and in the context of Pancasila and UUD 1945. The implications of the study in this article are formulated into three key recommendations: (a) the need to review and operational translation of Articles 33 and 34 of the UUD 1945 (Amendment IV, 2002); (b) the need to review the curriculum, learning approaches and tools, and practices of learning economics in schools in order that caring economic becoming educational character of the national economy; and (c) the need to campaign of introduction to paradigm and practice of caring economics in the universities, both as an academic study or studies the development of teaching-learning models based on caring economics, through collaboration of higher education, school, community and local government.
\end{abstract}

Keywords: caring economics, neo-liberal economics, pendidikan ekonomi, Pancasila, UUD 1945

JEL Classification: B51, P51

\section{PENDAHULUAN}

Pentingnya altruisme dan kompasionat dalam sistem ekonomi (altruism and compassionate in economic systems) mendorong Mind \& Life Institute (Zurich, Swis) pada bulan April 2010 menggelar konferensi yang berjudul "Altruism and Compassion in Economic Systems" untuk merespon pernyataan dan pertanyaan berikut:

Around the world, young people and families, scholars and workers, activists and politicians are calling for a more caring, sustainable, equitable economyone that does not accommodate the desires of a few elites but benefits the world's community through compassion and humanitarianism, and offers longterm care for future generations and the fate of the biosphere. Is such a system possible? What would it look like, and how could it change our world? (Singer, Richard \& Hangartner, 2015: 1. Penekanan oleh penulis).

Dihadiri tokoh-tokoh dari berbagai latar disiplin (ekonomi, neurosains, filsafat, praktisi kontemplatif, dan bisnis) bersama Dalai Lama ke 14 (Tenzin Gyatso), konferensi tersebut membahas dan merumuskan jawaban kutipan di atas. Hasil dari konferensi dikemas ke dalam sebuah buku berjudul "Caring Economics: Conversations on Altruism and Compassion, Between Scientists, 
Economists, and the Dalai Lama." (Editor: Tania Singer \& Matthieu Richard. New York: Picador, 2015).

Dalam Seminar Nasional Pendidikan Ekonomi yang bertema "Membangun Caring Economic melalui Pendidikan" (NCEE 2016 - Pascasarjana Universitas Negeri Malang, 27 Agustus 2016), buku tersebut menjadi rujukan pertama dari tiga rujukan utama yang saya gunakan untuk pfesentasi tentang konsep dan prinsip dasar yang tercakup di dalamnya. Rujukan kedua artikel Riane Eisler: "Building a Caring Economy and Society: Beyond Capitalism, Socialism, and Other Old Isms." (Cadmus, Vol. 1, Issue 6, May 2013, hlm. 49-65). Rujukan ketiga tulisan Thera van Osch: "Towards a Caring Economic Approach" (Netherlands, May 2013).

Analisis kritis pada tiga rujukan utama itu kemudian saya kaitkan dengan rujukan lain yang menurut saya relevan dan melengkapi konsep caring economics dalam konteks sosial dan lingkungan (social and environmental contexts), yaitu buku teks: "Principles of Economics in Context", yang disusun oleh Neva R. Goodwin et al. (diterbitkan M.E. Sharpe, Marmonk, New York, 2014).

Hasil analisis kritis pada tiga rujukan utama dan rujukan pelengkap itu kemudian saya kaitkan dengan konteks ekonomi dan pendidikan ekonomi nasional yang "seharusnya" digelar di sekolah dan perguruan tinggi, yakni ekonomi yang dicita-citakan dalam UUD 1945 dengan landasan Pancasila. Kata "seharusnya" sengaja saya pakai di sini untuk mengingatkan kembali kepada pembaca bahwa sejak UUD 1945 disahkan (18 Agustus 1945) hingga diamandemen keempat kalinya (10 Agustus 2002), untuk Bab XIV, Pasal 33 dan 34, yang mengatur perekonomian nasional dan kesejahteraan sosial belum secara resmi dan operasional dijabarkan lebih lanjut ke dalam Undang-undang (seperti yang dinyatakan dalam pasal 33, ayat 5, dan pasal 34, ayat 4). Apakah kita harus menunggu Undang-undang yang mengatur pelaksanaan kedua pasal itu? Tentu saja tidak. Upaya untuk menjabarkan secara operasional sudah dilakukan melalui berbagai kajian dalam forum akademik dan publik seperti penelusuran oleh Tarli Nugroho (2010a \& 2010b). ${ }^{1}$ Akan tetapi, hingga seminar ini digelar, saya belum melihat adanya langkah konkrit dari kementerian pendidikan dan kebudayaan dan kementerian riset dan teknologi pendidikan tinggi untuk mengkaji kembali dan merumuskan secara operasional, paling tidak tentang tiga hal strategis berikut:

(a) definisi operasional tentang arti dan aktualisasi pasal 33, ayat 1,2, 3, dan 4;

(b) latar filosofi dan teori (aliran pemikiran) ekonomi yang tepat, atau sangat dekat digunakan untuk menjabarkan (a); dan

(c) kontekstualisasi (a) dan (b) ke dalam berbagai pendekatan dan format pembelajaran dalam pendidikan ekonomi, baik di dalam maupun di luar sekolah atau kampus.

Pendekatan unobtrusive research (lihat misalnya: Babbie, 2011; Baker, 2008; Berg, 2001; Bryman, 2012; Kellehear, 1993; Lee, 2000; dan O’Brien, 2011) saya terapkan dalam menganalisis isi dan fenomena yang dipaparkan pada rujukan

\footnotetext{
1 Lihat:

a) Pemikiran Agraria Bulak Sumur: Telaah Awal atas Pemikiran Sartono Kartodirdjo, Masri Singarimbun, dan Mubyarto (Ed. E. Soetarto), Bab IV. "Mubyarto dan Ilmu Ekonomi yang Membumi." (Yogyakarta: STPN Press \& Sajogyo Institute, 2010). Hlm. 199-321.

b) "Ekonomi Pancasila Refleksi Setelah Tiga Dekade." (http://www.academia.edu/1500041/Ekonomi_Pancasila_Refleksi_setelah_Tiga_Dekade)
} 
utama dan pelengkap, kemudian saya bandingkan dengan rujukan yang mengkaji ekonomi berlandaskan Pancasila dan UUD 1945. Hasil kajian unobtrusive ini menjadi dasar untuk menyimpulkan sejauh mana caring economics layak menjadi karakter ekonomi dan pendidikan ekonomi nasional kita. Kelayakan itu membawa implikasi strategis: pengkajian dan perumusan kembali, dan pengembangan lanjut kurikulum pendidikan ekonomi pada semua jenjang pendidikan formal (dasar, menengah, tinggi), dalam berbagai format dan setting pembelajaran, dan dalam konteks serta relevansinya dengan harapan untuk mewujudkan "education for sustainable development."

\section{KONSEP \& PRINSIP DASAR CARING ECONOMICS Peristilahan: caring, economics, economy, economics}

Sebelum membandingkan isi dan konteks yang dimaksud di balik judul masing-masing rujukan utama yang disebut di atas, sebaiknya -- dan menurut saya perlu -- diklarifikasi lebih dahulu arti dan penggunaan istilah caring, economics, economy, dan economic.

Caring mencakup pengertian menjaga, merawat, memelihara, dan memperbaiki sesuatu berdasarkan sikap atau rasa peduli atas orang atau lingkungan. Kepedulian di sini dilandasi paham altruisme (altruism) (lebih mementingkan orang lain daripada kepentingannya sendiri) dan rasa iba, atau belas dan kasih (compassionate).

Dalam konteks ekonomi, caring bermakna ganda: sebagai aktivitas manusia di dalam mengelola sumber daya ekonomi untuk mencapai kemakmuran, dan lebih spesifik adalah kategori sektor atau bidang pekerjaan profesional (misalnya, perawat dan dokter di bidang kesehatan, pengasuh anak-anak di rumah tangga, pengasuh anak-anak di panti asuhan dan panti jompo, dan teknisi bagian perawatan dan peneliharaan).

Caring dalam judul masing-masing rujukan utama itu hendaknya ditafsirkan sesuai dengan arti dan penggunaan economics, economy, dan economic, dalam konteks atau fokus utama pemaparannya.

Untuk itu, kiranya kita bisa merujuk ringkasan hasil penelusuran S.M. Ariana \& P.A. Mirabela (2013) yang dipaparkan dalam "Economy, Economics, Economic, Economical" sebagai berikut:

Kata economics sebagai kata benda tunggal, selama ini digunakan untuk menyebut ekonomi sebagai bidang, atau disiplin ilmu sosial, ilmu ekonomi, yang berkaitan dengan urusan produksi dan konsumi barang dan jasa. Tetapi, bisa juga digunakan untuk menyebut analisis aktivitas komersial suatu masyarakat. Sebagai kata benda jamak, economics digunakan untuk menyebut aspek-aspek yang terkait dengan keuangan suatu proyek atau properti.

Kata economy lebih luas arti dan penggunaannya. Economy (alih bahasa Indonesia: ekonomi) memiliki sepuluh arti dan penggunaan: (1) pengelolaan sumberdaya yang hati-hati untuk menghindari pemborosan; (2) menabung, sebagai sarana atau ujud dari tindakan ekonomi; (3) menyisakan, menyisihkan, atau berhemat dengan tujuan untuk memperoleh hasil maksimum dengan upaya minimum, misalnya ekonomi waktu, ekonomi bahasa; (4a) suatu aktivitas manusia yang kompleks terkait dengan urusan produksi, distribusi, dan konsumsi barang dan jasa; (4b) cabang atau tipe tertentu dari urusan produksi, distribusi, dan konsumsi, misalnya ekonomi kapitalis, ekonomi sosialis, ekonomi pertanian; (5) menajemen sumber-sumber daya, keuangan, pendapatan, dan pengeluaran suatu komunitas, atau badan usaha; (6) kategori, klasifikasi, golongan, misalnya ekonomi lemah, ekonomi kuat, kelas ekonomi; (7) sebagai 
modifier dari (6), misalnya paket ekonomi; (8) keterkaitan yang beraturan antar bagian dari suatu sistem atau struktur, misalnya ekonomi alam (economy of nature); (9) prinsip (dalam filsafat) yang menyatakan bahwa dari dua teori yang bersaing, salah satunya kurang memiliki presuposisi ontologis yang ditawarkan; dan (10) (sudah lama tidak dipakai lagi) manajemen urusan rumah tangga, atau ekonomi domestik.

Kata economic, sebagai kata sifat, memiliki enam arti dan penggunaan: (1) sesuatu yang berhubungan dengan economics atau economy, atau dengan keuangan, misalnya pembangunan ekonomi (economic development), teori-teori ekonomi (economic theories); (2) (dari bahasa Inggris British) bisa diproduksi, dioperasikan, untuk memperoleh keuntungan, menguntungkan, misalnya dalam pernyataan "the firm is barely economic"; dan (3) menyangkut atau mempengaruhi sumberdaya material atau kesejahteraan, misalnya hama ekonomi (economic pests).

Dengan demikian, bisa dipahami bahwa caring economics pada rujukan pertama tentunya lebih banyak membicarakan ilmu atau sistem ekonomi yang terkait dengan pentingnya caring. Caring economy yang dimaksud pada rujukan kedua tidak hanya ilmu, sistem, dan pendekatannya, tetapi juga praktik bagaimana teori caring economy itu menjadi alternatif lain selain teori ekonomi yang sudah ada (kapitalis dan sosialis). Caring economics pada rujukan ketiga lebih fokus pada isi, bentuk, organisasi, lembaga, atau kebijakan ekonomi yang menggeser paradigma ekonomi neo-liberal menjadi "caring for human being".

\section{Perbandingan Pokok Konsep \& Prinsip Dasar}

Perbandingan pokok konsep dan prinsip dasar yang dipaparkan pada masing-masing rujukan dari tiga rujukan utama diringkas dalam Tabel 1 berikut.

Tabel 1. Konsep dan prinsip dasar Caring Economics

\begin{tabular}{|c|c|c|c|}
\hline & Rujukan Utama & Konsep Dasar & Prinsip Dasar \\
\hline 1. & $\begin{array}{l}\text { Caring Economics: } \\
\text { Conversations on } \\
\text { Altruism and } \\
\text { Compassion between } \\
\text { Scientists, } \\
\text { Economists, and The } \\
\text { Dalai Lama } \\
\text { (Eds. Singer \& } \\
\text { Richard, 2015. New } \\
\text { York: Picador). }\end{array}$ & $\begin{array}{l}\text { Sistem dan aksi ekonomi baru } \\
\text { yang berbasis "homo economicus } \\
\text { as fundamentally pro-social } \\
\text { being" } \\
\text { Manusia ekonomi tetap menjadi } \\
\text { watak dasar, tetapi orientasi } \\
\text { tujuan akhirnya diarahkan untuk } \\
\text { mencapai kemakmuran } \\
\text { masyarakat dan lingkungannya } \\
\text { (social well-being and } \\
\text { environment prosperity) }\end{array}$ & $\begin{array}{l}\text { Altruism dan kompasionat } \\
\text { menjadi prinsip dasar dalam } \\
\text { mengubah paradigma "self- } \\
\text { interest homo economicus" } \\
\text { menuju "human being and } \\
\text { environment-interst homo } \\
\text { economicus" } \\
\text { Caring = tindakan ekonomi } \\
\text { yang dimotivasi oleh peduli } \\
\text { dan belas-kasih pada orang } \\
\text { lain dan lingkungannya } \\
\text { (altruism \& compassionate). }\end{array}$ \\
\hline 2. & $\begin{array}{l}\text { Building a Caring } \\
\text { Economy and } \\
\text { Society: } \\
\text { Beyond Capitalism, } \\
\text { Socialism, and Other } \\
\text { Old Isms } \\
\text { (Eisler, 2013. } \\
\text { Cadmus, Vol. 1, } \\
\text { Issue 6, May 2013, } \\
\text { hlm. 49-65). }\end{array}$ & $\begin{array}{l}\text { Membangun ekonomi dan } \\
\text { masyarakat berbasis "caring for } \\
\text { people as well as for natural } \\
\text { environment." } \\
\text { Landasan "caring for people and } \\
\text { nature" (pengutamaan pada } \\
\text { manusia dan lingkungan } \\
\text { alamnya) menjadi acuan dalam } \\
\text { membangun sistem dan tindakan } \\
\text { ekonomi. }\end{array}$ & $\begin{array}{l}\text { Sistem dan tindakan ekonomi } \\
\text { masyarakat berbasis "caring } \\
\text { for people \& natural } \\
\text { environment" bisa } \\
\text { diwujudkan melalui dua } \\
\text { prinsip: } \\
\text { 1) Mengubah ranah soal dan } \\
\text { kajian ekonomi yang } \\
\text { selama ini hanya mengurus } \\
\text { "market economy", } \\
\text { "government economy", } \\
\text { dan "illegal economy" } \\
\text { menuju ekonomi dengan } \\
\text { spektrum lengkap/utuh }\end{array}$ \\
\hline
\end{tabular}




\begin{tabular}{|c|c|c|c|}
\hline & & & $\begin{array}{l}\text { 2) Menggeser paradigma } \\
\text { sistem sosial, dari } \\
\text { "domination system" } \\
\text { menuju "partnership } \\
\text { system." }\end{array}$ \\
\hline 3. & $\begin{array}{l}\text { Towards a Caring } \\
\text { Economic Approach } \\
\text { (Van Osch, } 2013 . \\
\text { Netherlands, May } \\
\text { 2013). }\end{array}$ & $\begin{array}{l}\text { Menggeser paradigma berpikir } \\
\text { ekonomi dari "homo } \\
\text { economicus" menuju "caring for } \\
\text { human being." } \\
\text { Perubahan paradigma berpikir } \\
\text { menuju "caring for human } \\
\text { being" mensyaratkan perubahan } \\
\text { mendasar konsep-konsep dan } \\
\text { teori yang selama ini berkiblat } \\
\text { pada ekonomi neo-liberal. }\end{array}$ & $\begin{array}{l}\text { Pendekatan dalam berpikir } \\
\text { dan bertindak ekonomi } \\
\text { diubah dari "menghimpun } \\
\text { kekayan untuk diri sendiri" } \\
\text { menjadi "memakmurkan } \\
\text { semua orang dan menjaga } \\
\text { kelangsungan hidup di planet } \\
\text { ini." } \\
\text { Pendekatan itu bisa dilakukan } \\
\text { melalui perubahan paradigma } \\
\text { berpikir/pemikiran "neo- } \\
\text { liberal economics" menuju } \\
\text { "caring economic for human } \\
\text { being." }\end{array}$ \\
\hline
\end{tabular}

\section{CARING ECONOMICS = Pro-Scociality in Economic Systems}

Sistem ekonomi pro-social being yang didambakan (envisioned) dalam rujukan pertama saya temukan pada Bagian III Introducing Pro-Sociality into Economic Systems, Bab 11 Profit with a Purpose, yang disajikan Antoinette Hunziker-Ebtener (hlm. 137-145). Hunziker-Ebtener adalah CEO dan pendiri Forma Futura Invest Inc., perusahaan manajemen aset independen fokus pada oportunitas investasi yang menggabungkan antara konsep, prinsip, dan praktik good governance dengan social and environmental responsibility. Menurut dia, investasi keuangan pada perusahaan yang tepat dapat mempromosikan kesejahteraan sosial dan lingkungan sembari menghasilkan keuntungan finansial. Konsep, prinsip, dan praktik yang dimaksud diilustrasikan seperti Gambar 1 berikut.

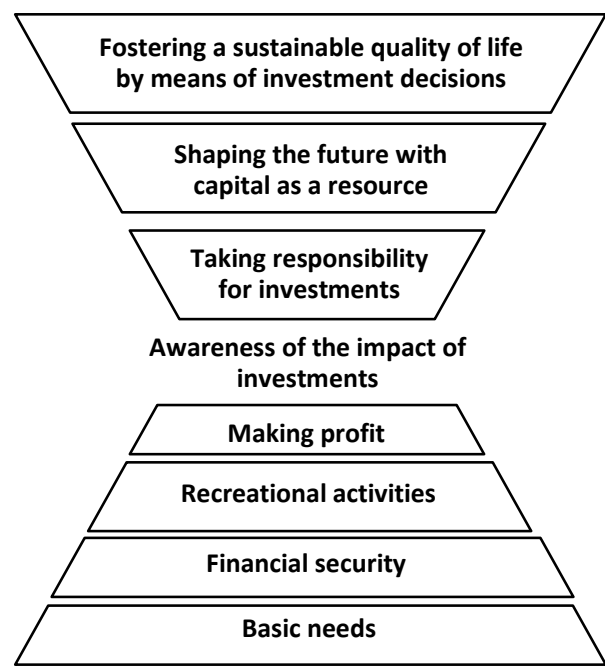

Gambar 1. Investasi lebih dari sekadar memperoleh keuntungan Sumber: Hunziker-Ebtener, 2015, hlm. 139

Piramida di atas menggambarkan kebutuhan finansial manusia. Pertamatama kita butuh uang untuk memenuhi kebutuhan dasar (basic needs), misalnya: 
makan, minum, rumah, dan pendidikan. Setelah tercapai, kita harus menyisihkan sebagian uang untuk mengantisipasi kebutuhan yang tidak terduga, misalnya ketika sakit (financial security). Mengumpulkan lagi sejumlah uang untuk memenuhi kebutuhan rekreasional, misalnya olah raga, menikmati wisata dan seni (recreational activities). Dalam kurun waktu berikutnya kita ingin memperoleh sejumlah keuntungan (making profits). Jika kita berhasil memenuhi keempat level itu, dan kita kemudian menyadari betapa hasil yang kita capai itu adalah dampak dari investasi yang kita lakukan (awareness of the impact of investments), maka seharusnya kesadaran itu mendorong kita untuk turut serta mengambil kesempatan berinvestasi lebih lanjut guna berkontribusi untuk mencapai suatu kualitas kehidupan yang lebih baik: (1) taking responsibility for investments, (2) shaping the future with capital as a resource, and (3) fostering a sustainable quality of life by means of investment decisions). Apa yang digambarkan Hunziker-Ebtener itu pada dasarnya menjadi impian atau cita-cita bagi setiap manusia. Dampaknya tidak diukur dari berapa besar nilai investasinya, tetapi dari seberapa besar investasi itu pada akhirnya dapat mewarnai perubahan yang diharapkan dalam konteks lokal maupun global. Menurut Hunziker-Ebtener kuncinya terletak pada cara bagaimana agar investasi itu sejalan dengan perubahan menuju kualitas kehidupan yang lebih baik dan berkelanjutan (sustainable quality of life). Ia mengandaikan perubahan itu sebagai transformasi investasi yang kontingen dengan empat (r)evolusi (harap dibaca: revolusi, atau evolusi) global dalam Gambar 2 berikut.

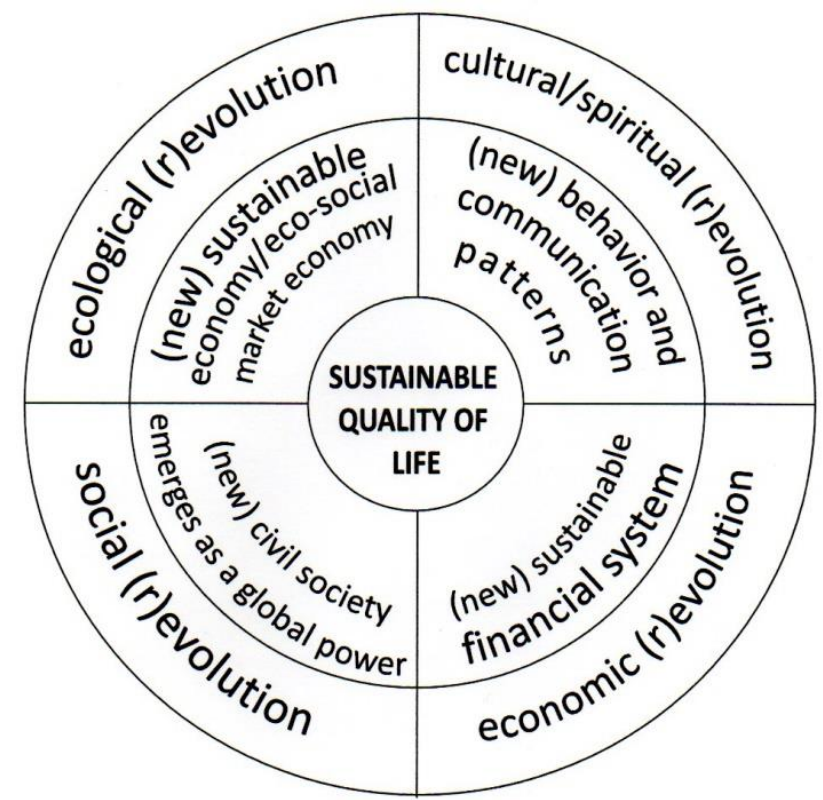

Gambar 2. Transformasi investasi menuju kualitas hidup berkelanjutan dalam (r)evolusi global

Sumber: Hunziker-Ebtener, 2015, hlm. 141

Hunziker-Ebtener cenderung memilih pendekatan evolusioner dalam perubahan global di atas, dengan urutan argumentasi sebagai berikut (adaptasi dari Hunziker-Ebtener, 2015, hlm. 141-142):

(1) Diawali dengan perubahan ekologis yang bertolak dari perubahan ekonomi yang berkelanjutan, ekonomi yang berbasis eko-sosial, dan ekonomi pasar 
yang semuanya harus care dengan lingkungan. Misalnya, jika seseorang, atau perusahaan mengakibatkan emisi gas (efek rumah-kaca) maka ia harus membayar kerugiannya. Kita harus memasukkan biaya kerusakan lingkungan dalam penetapan harga.

(2) Upaya pertama di atas harus didukung/diikuti oleh sistem finansial yang dimulai dari penetapan sasaran yang masuk akal (setting reasonable goals), yaitu dengan menetapkan apa target dari sistem ekonomi kita. Apakah ukuran GDP masih memadai? Tidak lagi, karena GDP tidak mengukur kualitas hidup.

(3) Dua perubahan sebelumnya harus diikuti oleh perubahan sosial, di mana kemunculan gerakan masyarakat madani akan menjadi salah satu kekuatan global. Gerakan ini memiliki ciri penuh tanggung jawab dan sadar sepenuhnya apa dan berapa barang-barang yang dikonsumsi. Masyarakat yang demikian ini tidak lagi membutuhkan barang yang secara fisik mewah, tetapi lingkungan yang aman, nyaman, bersahabat, penuh bahagia, yang membuat hidup penuh makna.

(4) Terakhir, semua perubahan di atas tidak akan lengkap jika tidak disertai perubahan kultural dan spiritual, yang direfleksikan melalui perubahan polapola perilaku dan komunikasi yang mengarah pada perdamaian, persaudaraan, anti kekerasan.

\section{CARING ECONOMICS = Caring for People \& Natural Environment}

Riane Eisler dalam rujukan kedua memulai tesisnya dengan menyatakan

Old economic approaches are not capable of meeting our economic, environmental, and social challenges. To effectively meet these challenges, we need a perspective that goes beyond the conventional capitalism vs. socialism debate. (Hlm. 49)

Perspektif yang dimaksud sebelumnya sudah ia paparkan dalam salah satu bukunya yang berjudul "The Real Wealth of Nations: Creating a Caring Economy" (San Francisco: Berret-Koehler, 2007). ${ }^{2}$ Dalam artikel yang dijadikan rujukan kedua di sini ia menekankan kembali betapa pentingnya perspektif baru dalam sistem ekonomi yang mampu menjawab persoalan ekonomi, lingkungan, dan sosial secara bersama dan menyeluruh (holistik). Perspektif baru yang diusung dikemas ke dalam dua paradigma: (1) reframing the economic map, dan (2) shifting from domination to partnership systems.

\section{Reframing the Domain of Economics}

Selama ini sistem ekonomi kapitalis dan sosialis hanya mengurus tiga sektor: ekonomi pasar (market economy), ekonomi negara atau pemerintahan (governmental economy), dan ekonomi ilegal atau informal (illegal or informal economy). Pada hal, ada tiga sektor ekonomi lain yang selama ini memiliki nilai riil dalam menyangga kehidupan (the real value of the three life-sustaining economic sectors): ekonomi rumah tangga (household economy), ekonomi alamiah (natural economy), dan ekonomi tidak berbayar atas dasar suka-rela (unpaid or volunteer economy). Ketiga sektor inilah yang sebenarnya menjadi pilar bangunan sistem ekonomi yang mengurus manusia dan lingkungannya (alam, sosial, dan budaya) yang berbasis caring for people and natural environment. Karena itu, menurut Eisler spektrum ranah kajian dan urusan

2 Direview oleh T.F. Hawk (2011). "The Real Wealth of Nations: Creating a Caring Economics". Academy of Management Learning \& Education, December 2011, hlm. 739-743. 
ekonomi harus disusun ulang (reframing) ke dalam suatu peta yang utuh, seperti dalam Gambar 3 berikut.

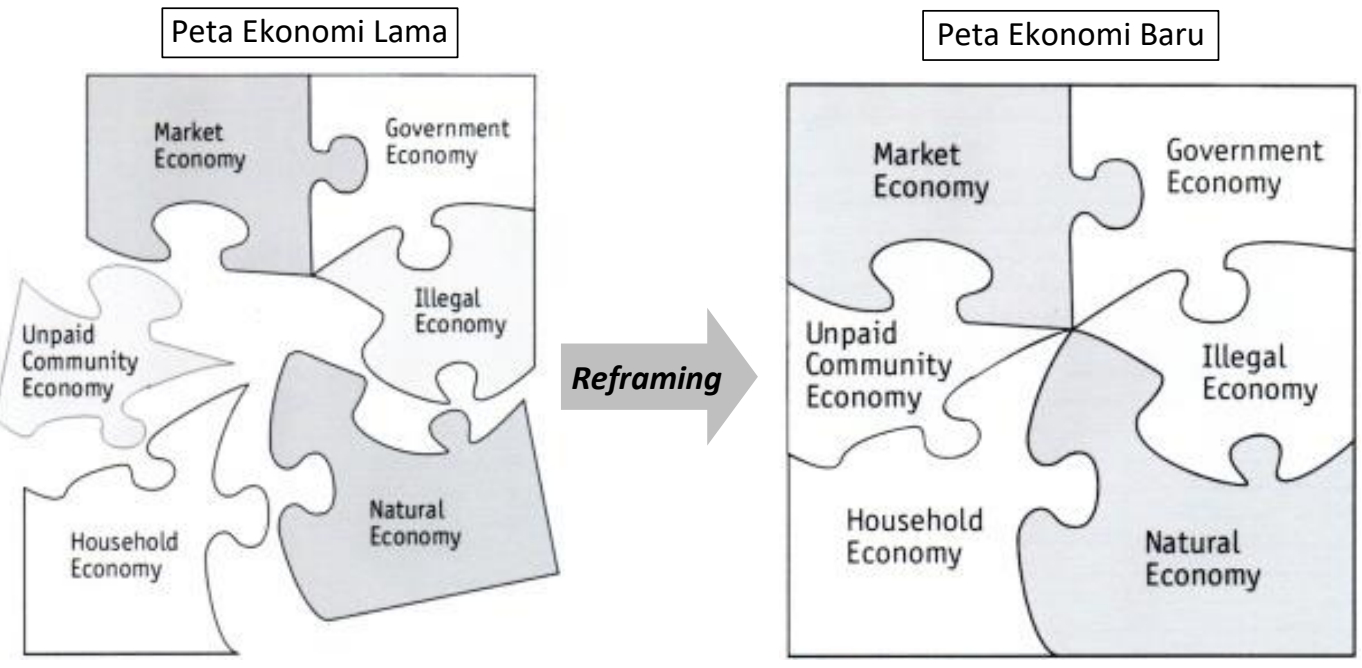

Gambar 3. Pemetaan (reframing) ranah kajian ekonomi

Sumber: Eisler, 2013, hlm. 50 \& 52

Peta ekonomi baru di atas menuntut perubahan paradigma berpikir dan bertindak yang belum pernah dilakukan, yaitu memasukkan sektor unpaid community economy, household economy, dan natural economy, sebagai bagian integral dari sistem ekonomi baru. Ketiga sektor ini semula dianggap bukan productive menjadi reproductive, karena:

Economic systems do not arise in a vacuum. They are influenced by, and in turn influence, the larger social system in wich they are embedded. (Eisler, 2013, hlm. 52).

Dalam sistem ekonomi baru tidak berarti menggusur semua teori ekonomi yang sudah ada, tetapi bergerak maju ke arah suatu sistem ekonomi yang memberi visibilitas dan nilai nyata kepada pekerjaan manusia yang esensial: the work of caring for our natural environment and caring for people, starting in chlidhood (hlm. 52).

\section{Shifting from Domination to Partnership Systems}

Sistem ekonomi baru itu akan efektif jika diiringi dengan pergeseran paradigm berpikir dan bertindak dari sistem sosial yang mendominasi (domination system) menuju sistem sosial kemitraan (partnership system) seperti dalam Gambar 4. Sistem sosial yang mendominasi analog dengan struktur piramida. Sistem sosial ini mendukung adanya hirarki peringkat hubungan top-down yang terkesan "menindas", misalnya: laki-laki atas wanita, bangsa atas bangsa, agama atas agama. Ada tiga komponen inti yang secara bersama mendukung sistem sosial ini: (a) kendali top-down baik di dalam keluarga, suku, atau negara; (b) laki-laki menjadi dominan, di sini terjadi devaluasi oleh laki-laki dan wanita terhadap sesuatu yang stereotipis dianggap "feminine", termasuk pekerjaan yang tergolong care dan care giving; dan (c) dukungan, bahkan idealisasi, terhadap tindakan kekerasan sebagai sarana untuk memaksakan kehendak satu pihak terhadap pihak lain. Dalam konteks ekonomi, sistem sosial ini tercermin dalam praktik ekonomi kapitalis atau neo-liberal, yang cenderung tidak adil dan eksploitatif (unjust and exploitative). Dalam perspektif ini yang dimaksud bukan 
semata kapitalisme dan neo-liberalisme itu sendiri, tetapi terhadap paham-paham (beliefs), lembaga-lembaga, dan relasi-relasi inheren yang mendominasi dalam sistem sosial itu.

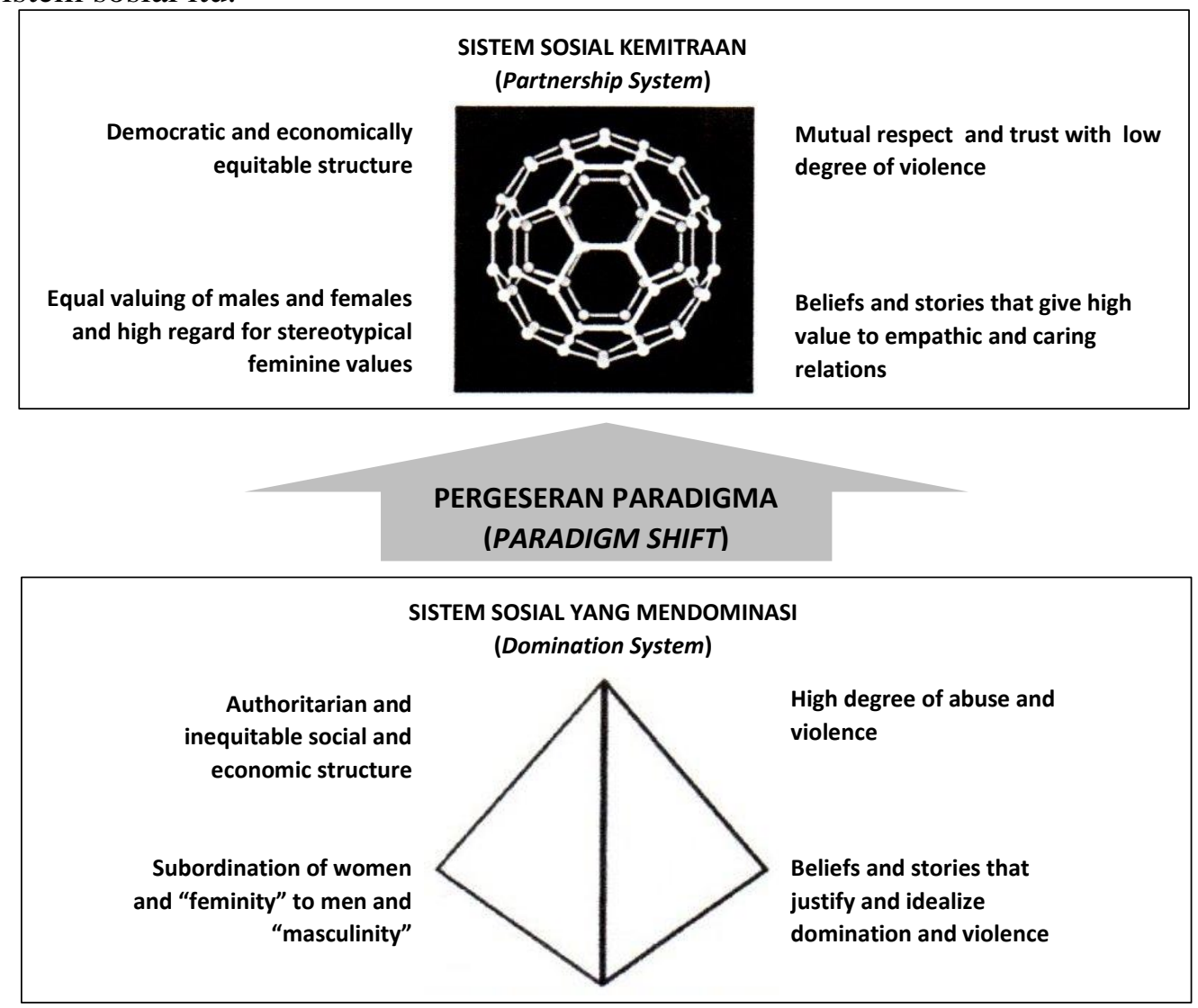

Gambar 4. Pergeseran paradigma sistem sosial, dari dominasi menuju kemitraan Sumber: Adaptasi dari Eisler, 2013, hlm. 55

Sistem sosial kemitraan analog dengan struktur jejaring (networks structure). Sistem sosial ini mendukung hubungan antara sistem sosial dan sistem ekonomi dalam posisi saling menghargai, saling akuntabel, saling menguntungkan (mutual respect, accountability, and benefit). Harap dicatat, tidak berarti bahwa kooperatif itu hanya ada dalam sistem kemitraan. Selama ini orang-orang dalam sistem sosial yang mendominasi juga menjalin hubungan kemitraan yang kooperatif: kerjasama monopolis, kerjasama kelompok kriminal atau teroris, dan kerjasama militer antar negara dalam menginvasi suatu negara. Selain itu, dalam sistem kemitraan tidak melulu strukturnya datar, tetapi ada hirarki yang mendominasi dimana saling menghargai, saling akuntabel, dan saling menguntungkan itu mengalir dari bawah ke atas (bottom-up). Sehingga, hirarkinya mengarah pada aktualisasi di mana kekuasaan tidak digunakan untuk melemahkan, tetapi untuk menguatkan yang lain (hierarchies of actualization, where power is not used to disempower, but to empower others).

Pergeseran paradigma sistem sosial dari yang mendominasi menuju kemitraan di atas dalam praktik tidak bersifat dikotomis, tetapi kontinum, seperti pendulum, ke arah mana kecenderungan sistem sosial itu berayun. 


\section{PARADIGM SHIFT: From Homo Economicus to Caring Human Being}

Rujukan ketiga yang ditulis Thera van Osch (2013) menurut saya lebih operasional, kontekstual, dan aplikabel, dibanding dua rujukan sebelumnya. Hal ini bisa dilihat dari struktur, alur paparan, dan isi pesan atau pengetahuan yang disampaikan, mulai dari konsep dan definisi tentang "care" dan "economy of care", pembandingan paradigma berpikir ekonomi neo-liberal dan caring economic, formulasi model economy of care, hingga rekomendasi yang ia usulkan bagaimana economy of care itu bisa diterapkan secara makro (kebijakan makro ekonomi).

\section{Konsep dan Definisi: Care \& Economy of Care}

Pada dasarnya konsep care memiliki beberapa arti. Ia bisa mengacu pada seperangkat nilai, sikap, dan praktik yang membangun relasi sosial antar orang dan lingkungannya. Kehidupan manusia dimulai dengan menerima care. Tanpa care, seorang anak tidak dapat bertahan hidup. Karena itu, konsep care adalah pengalaman sejati yang universal (care is therefore a truly universal experience). Semua budaya mempertahankan hidupnya dilandasi oleh etika dan care, yang mencakup regulasi dan tata-cara atau adat bagaimana: ... people care for themselves, for each other and for their environment. Konsep care krusial bagi keberlanjutan sosial (social sustainability), karena tanpa adanya care, bisa terjadi disintegrasi sosial, pengabaian atau penelantaran (anak, orang tua, fasiltas sosial, dan lingkungan alam), yang berujung lenyapnya kehidupan sosial. Konsep care juga krusial bagi keberlanjutan ekologis (ecological sustainability), karena tanpa adanya care terhadap dampak ulah manusia terhadap lingkungannya (penggundulan hutan, pencemaran air, udara, dan tanah), maka ekologi terancam punah. Ringkas kata, konsep care tidak hanya menunjuk pada aktivitas rutin rumah tangga atau pekerjaan di sektor care, tetapi menyangkut pula suatu sikap atau orientasi moral (an attitude or moral orientation) yang dilandasi oleh nilai intrinsik berupa kepekaan terhadap kehidupan (sense of life).

Definisi kerja economy of care menurut van Osch (2013, hlm. 5) diadaptasi dari konsep care menurut J.C. Tronto (1993) ...

"everything that we do to maintain, continue, and repair our 'world' so that we can live in it as well as possible. That world includes our bodies, ourselves, our environment, all of which we seek to interweave in a complex, life-sustaining web."

yang kemudian dirumuskan bahwa economy care adalah ...

The science of human behaviour focused on maintaining, continuation, and repairing the world in which we live, in order to improve quality of life for all in a sustainable way. [Ilmu tentang perilaku manusia berfokus pada pemeliharaan, kontinyuasi, dan perbaikan dunia di mana kita hidup, untuk memperbaiki kualitas kehidupan bagi semua dengan cara yang berkelanjutan] (Hlm. 5).

Definisi kerja di atas menurut van Osch memang sudah ada dan selalu begitu, kapan saja, di mana saja. Karena, nilai dari "care" itu bertolak dari pengalaman sejati manusia secara universal. Kita akan hidup dalam dunia secara total berbeda jika care untuk kita sendiri, untuk teman-teman kita sesama manusia dan lingkungan kita juga menjadi basis untuk pemikiran dan kebijakan ekonomi (we would be living in a totally different world if care for ourselves, for our fellow humans and our environment would also be the basis for economic thought and policy). 


\section{Paradigma \& Suposisi: Ekonomi Neo-liberal vs. Caring Economic}

Dua rujukan terdahulu sudah menegaskan perbedaan mendasar paradigma (sudut pandang atau basis berpikir) antara caring economics dan capitalist atau neo-liberal economics. Thera van Osch dalam hal ini lebih spesifik dan kontekstual dalam membandingkan paradigma ekonomi neo-liberal dan caring economic berdasarkan suposisi, (supposition, bisa berarti asumsi, anggapan, andaian, atau kiraan) yang mendukung paradigmanya. Ada lima topik dalam kajian ilmu ekonomi yang dijadikan perbandingan antara suposisi dalam ekonomi neo-liberal dan caring economic:

(1) perilaku manusia (human behavior);

(2) konsumsi (consumption);

(3) produksi (production);

(4) tenaga kerja (labor);

(5) distribusi (distribution).

Tabel 2, 3, 4, 5, dan 6 berikut membandingkan paradigma dan suposisi neo-liberal (selanjutnya disingkat: NL) dan caring economic (selanjutnya disingkat: CE), masing-masing diadaptasi dari van Osch, 2013, hlm. 5, 6, 9, 11, dan 12.

Tabel 2. Paradigma/Suposisi tentang Perilaku Manusia

\begin{tabular}{ll}
\hline \multicolumn{1}{c}{ Neo-liberal } & \multicolumn{1}{c}{ Caring Economic } \\
\hline $\begin{array}{l}\text { Rational Economic Man (homo } \\
\text { economicus): concept about humans based } \\
\text { on utilitarianism }\end{array}$ & $\begin{array}{l}\text { Caring human being: concept about } \\
\text { interrelated persons - acting on the basis of } \\
\text { mutual trust and sensitivity - based on the } \\
\text { philosophy of Ethics of Care }\end{array}$ \\
\hline $\begin{array}{l}\text { By pursuing self-interest you serve public } \\
\text { interest }\end{array}$ & $\begin{array}{l}\text { By caring for oneself, for each other and for } \\
\text { the environment, the social formation will } \\
\text { become sustainable }\end{array}$ \\
\hline $\begin{array}{l}\text { Explains efficient allocation of scarce goods } \\
\text { through the market (subjective value theory) }\end{array}$ & $\begin{array}{l}\text { Explains human survival and works in all } \\
\text { circumstances, including times of war and } \\
\text { crisis (intrinsic value theory/existential values) }\end{array}$ \\
\hline $\begin{array}{l}\text { One-dimensional relations among } \\
\text { indviduals (exchange of goods and services) }\end{array}$ & $\begin{array}{l}\text { Holistic; multi-dimensional human relations; } \\
\text { mutual care, trust and responsiveness }\end{array}$ \\
\hline $\begin{array}{l}\text { Atomic society (sum of autonomous acting } \\
\text { independent individuals) }\end{array}$ & $\begin{array}{l}\text { Social connectedness; interdependency; } \\
\text { (persons embedded in histrorical, familial, } \\
\text { social economic, political, ethnical context) }\end{array}$ \\
\hline
\end{tabular}

Manusia ekonomi (homo economicus) dalam pandangan NL adalah individu yang independen, otonom, dan rasional, yang mengejar kepuasan maksimum dengan biaya minimum. Dalam pasar bebas perilaku manusia ini dianggap tentu mengalokasikan barang dan jasa yang langka secara efisien. Masyarakat diangap kumpulan dari semua individu yang bertindak rasional. Sayangnya konsep satu dimensi ini hanya sebuah konstruksi teoretis. Dalam kehidupan nyata orang yang demikian itu akan memiliki perilaku anti-sosial: terisolasi secara sosial, tanpa emosi, tanpa kesadaran moral, dan tanpa punya hubungan dengan orang lain, hanya fokus pada keputusan-keputusan pengambilan tindakan rasional untuk mencapai kepuasan maksimum kebutuhannya dengan biaya minimum dan tanpa mempertimbangan kebutuhan dan keinginan pihak lain 
lain. ${ }^{3}$ Konsep care tidak dikenal dalam NL. CE berangkat dari pendekatan lebih integral tentang perilaku manusia dan mencoba memahami nilai-nilai yang paling dasar dan komprehensif. Caring human being menduduki tempat pertama dalam hubungan saling bergantung antar orang, terkoneksi secara sosial, yang diperngaruhi oleh dan terlibat dalam relasi dengan orang lain. CE memerlukan saling percaya antar orang-orang yang terlibat. Adalah caring human being yang menjaga kelangsungan masyarakat, ketika keadaan sedang baik atau buruk, pada situasi krisis dan perang, dalam ekonomi formal maupun informal, dalam masyarakat tradisional maupun moderen; CE selalu ada di sana; setiap hari dan di mana saja. Care adalah fitur kunci konteks manusia global di mana ekonomi pasar berada. Bahkan walaupun pasar runtuh, CE terus berfungsi.

Tabel 3. Paradigma/Suposisi tentang Konsumsi

\begin{tabular}{ll}
\hline \multicolumn{1}{c}{ Neo-liberal } & \multicolumn{1}{c}{ Caring Economic } \\
\hline $\begin{array}{l}\text { Households are consumption units and do } \\
\text { not contribute to the production }\end{array}$ & $\begin{array}{l}\text { Households produce, consume, and generate } \\
\text { current future people }\end{array}$ \\
\hline $\begin{array}{l}\text { Consumption is determined by the 'law of } \\
\text { the subjective value theory' (marginal }\end{array}$ & $\begin{array}{l}\text { Consumption is also determined by generational } \\
\text { and gender relations within different social } \\
\text { classes and cultural groups (power relations) }\end{array}$ \\
\hline $\begin{array}{l}\text { Consumers should be encouraged to } \\
\text { maintain economics growth (creation of } \\
\text { needs in order to stimulate effecive } \\
\text { demand) }\end{array}$ & $\begin{array}{l}\text { Consumers should be encouraged to consume } \\
\text { sustainably and contribute to a global social and } \\
\text { ecological balance }\end{array}$ \\
\end{tabular}

NL memandang rumah tangga hanya sebagai unit konsumsi. Hanya perannya sebagai konsumen itulah rumah tangga dianggap relevan dalam model NL. Pekerja yang tak berbayar (unpaid work) dalam jumlah besar yang fokusnya melayani pekerjaan harian dan reproduksi generasional (mis. merawat anak-anak) dalam NL tidak dikenal, walaupun pekerjaan itu bagian dari ekonomi rumah tangga. Golongan pekerjaan ini, termasuk yang berbasis suka-rela (volunteer), pada tingkat makro-ekonomi tidak dimasukkan dalam perhitungan dan pengukuran pertumbuhan ekonomi. ${ }^{4}$

Dalam NL ada kontradiksi pada kategori unit konsumsi, yaitu bertentangan dengan paradigmanya sendiri bahwa homo economicus sebagai prinsip ekonomi pasar bebas. Statistik ekonomi-makro mengukur konsumsi itu dari satuan konsumsi, bukan dari konsumsi individual. Ini tidak sejalan dengan suposisi dalam teori NL bahwa tiap individu konsumen memiliki fungsi utilitas marjinalnya sendiri yang dinyatakan menurut teori nilai subjektif barang dan jasa yang diperoleh di pasar. Dengan menggunakan unit kosumsi sebagai kategori untuk mengukur perilaku konsumen, NL menganggap tidak ada perbedaan pendapat terhadap pemakaian sumberdaya pada unit konsumsi di tingkat rumah

3 Analisis lebih mendalam tentang homo economicus dalam paradigma neo-klasik lihat misalnya Irene van Staveren dalam "The Value of Economics: An Aristotelian Perspective." (London: Routledge-Taylor \& Francis Group. 2001).

4 Anehnya, pada tingkat mikro-ekonomi, NL banyak melakukan penelitian untuk menjelaskan ketimpangan pendapatan antara "paid work" dan "unpaid work" laki-laki dan perempuan, bahkan dalam kasus-kasus meningkatnya peluang pasar tenaga kerja bagi perempuan. Misalnya Gary S. Becker dalam "A Theory of the Allocation Time" (The Economic Journal, September 1965, hlm. 493-517); lihat juga telaah lanjut oleh J. Heckman (2014) dalam "Introduction to A Theory of the Allocation of Time by Gary Becker." (IZA Discussion Paper No. 8424. August 2014). 
tangga. NL menganggap bahwa, misalnya seorang pembantu rumah tangga, ketika membeli barang dan jasa untuk majikannya, dianggap sudah mengetahui semua preferensi anggota rumah tangga majikannya, sehingga ketika ia berbelanja justru menerapkan pendekatan altruistik. Altruistik inilah yang kontradiktif dengan prinsip utilitas marjinal NL.

CE memandang ekonomi yang berbayar (paid economy) dan yang tak berbayar (unpaid economy) sama pentingynya, dan memasukkan "unpaid labor" ke dalam model kebijakan ekonomi. Indikator untuk pengukuran kedua ekonomi tersebut sudah dikembangan melalui "PW-Quote" (Paid-Work Quote) yang menunjukkan rasio (dalam \%) antara total volume PW (Paid Work) dan UW (Unpaid Work) (dalam satuan waktu):

$$
\begin{aligned}
& \text { PW-quote }=\frac{\text { VPW }}{\text { VPW }+V U W} \text { X 100\% } \\
& \text { VPW = Volume Paid Work (waktu) } \\
& \text { VUW = Volume Unpaid Work (waktu) }
\end{aligned}
$$

CE mengakui perbedaan sosial terkonstruksi dalam relasi antara laki-laki dan wanita, dan antar generasi yang satu dengan yang lain, yang menentukan kekuasaan untuk memutuskan penggunaan pendapatan dan sumberdaya yang dimiliki keluarga, termasuk penggunaan waktu untuk tenaga kerja baik yang dibayar maupun tak berbayar. CE mendorong konsumsi itu dilakukan dengan cara yang "sustainable" dan untuk mewujudkan keseimbangan sosial dan ekologis secara global. Di sini, model fungsi kosumsi akan diganti dengan model fungsi penggunaan spasi lingkungan, atau dikenal dengan Environmental Space Used (ESU), yang juga dikenal sebagai "ecological footprint". ESU per kapita menunjukkan footprint ekologis kita. Berapa banyak sumberdaya yang kita gunakan? Berapa luas tanah pertanian yang dibutuhkan untuk menghasilkan makanan kita? Berapa luas spasi (ruang) yang kita butuhkan untuk menampung sampah yang kita hasilkan? Misalnya, USE untuk menghasilkan $1 \mathrm{~kg}$ daging sapi yang dipelihara secara organik adalah $261 \mathrm{~m} 2$, dan USE untuk menghasilkan $1 \mathrm{~kg}$ sayur segar adalah 9,7 m2. Footprint ekologis ini untuk mengukur permintaan manusia akan ekosistem, dan dapat dihitung untuk tiap orang, tiap sektor, bagi perusahaan, bagi kota, dan bagi negara. (Diadaptasi dari kutipan van Osch, 2013, hlm. 20, Box 6). Pengeluaran-pengeluaran konsumtif dalam CE akan dinyatakan dalam satuan ESU, bukan uang. Sistem perpajakan akan memberlakukan pemberian ganjaran bagi konsumen yang berperilaku "sustainable", dan pengenaan denda bagi konsumen yang berperilaku "harmful for people and the planet".

Tabel 4. Paradigma/Suposisi tentang Produksi

\begin{tabular}{ll}
\hline \multicolumn{1}{c}{ Neo-liberal } & \multicolumn{1}{c}{ Caring Economic } \\
$\begin{array}{l}\text { Production-unit: Optimal use of production } \\
\text { factors assumes perfect market } \\
\text { gompetition (markets for labor, for capital }\end{array}$ & $\begin{array}{l}\text { Production-unit: Optimal use of production } \\
\text { factors in terms of achieving human sustainable } \\
\text { development, including corporate ethics on } \\
\text { human rights, gender equality and } \\
\text { environmentally sound production methods }\end{array}$ \\
\hline $\begin{array}{l}\text { Adverse human and environmental costs } \\
\text { are not discounted from GDP }\end{array}$ & $\begin{array}{l}\text { GDP is correted by adverse human and } \\
\text { environmental costs }\end{array}$ \\
\hline $\begin{array}{l}\text { The value of unpaid work is taken for } \\
\text { granted and not included in the GDP }\end{array}$ & $\begin{array}{l}\text { The GDP includes the value of all and unpaid } \\
\text { production }\end{array}$ \\
$\begin{array}{l}\text { Accountability in terms of money; profit is } \\
\text { condition for economic sustainability }\end{array}$ & $\begin{array}{l}\text { Accountability and tranparency in terms of } \\
\text { echieving human rights, equality, and fair }\end{array}$ \\
\hline
\end{tabular}




\begin{tabular}{ll}
\hline annual report) & $\begin{array}{l}\text { ecological footprint, besides monetary gains } \\
\text { (annual report could be based on ISO 26000) }\end{array}$ \\
\hline $\begin{array}{l}\text { Production organized in private enterprises } \\
\text { which produce for the market and the } \\
\text { profits }\end{array}$ & $\begin{array}{l}\text { Broader approach: Everyone can produce: for } \\
\text { the market, for one-self, for the family or } \\
\text { community }\end{array}$ \\
\hline $\begin{array}{l}\text { Poduction of exchange values (monetary } \\
\text { values; prices on the market) }\end{array}$ & $\begin{array}{l}\text { Production of use values, which can also have } \\
\text { exchange value on the market, or values in } \\
\text { terms of reciprocity, barter, local exchange } \\
\text { sytems, or solidarity values etc. }\end{array}$ \\
\hline $\begin{array}{l}\text { Focus on increasing productivity for } \\
\text { permanent economic growth }\end{array}$ & $\begin{array}{l}\text { Focus on technical innovation to embed } \\
\text { economic activities in the natural circulation } \\
\text { systems and the social biological rhytm of } \\
\text { people, while maintaining intrinsic values which } \\
\text { are important for the quality of life }\end{array}$ \\
\hline $\begin{array}{l}\text { Production of destructive means for } \\
\text { warfare (such as guns, missiles, and other } \\
\text { weapons) contribute to economic growth }\end{array}$ & $\begin{array}{l}\text { Production of destructive means for warfare are } \\
\text { a cost for society and will reduce social and } \\
\text { economic growth }\end{array}$ \\
\hline $\begin{array}{l}\text { Production is globalized through the } \\
\text { market }\end{array}$ & $\begin{array}{l}\text { Production is part of global circulation system, } \\
\text { which includes the market as well as the unpaid } \\
\text { economy and the ecologial system }\end{array}$ \\
\hline
\end{tabular}

NL menganggap bahwa prinsip maksimisasi keuntungan ditentukan oleh penggunaan optimal faktor-faktor produksi (tenaga kerja, bahan mentah, dan modal). Namun, hal ini menuntut kondisi persaingan sempurna untuk mencapai tujuannya. Adanya "price-fixing" oleh para kartel, perusahaan monopolistik dan oligopolistik dapat menetapkan harga di atas harga pasar tanpa lewat persaingan. Konsekuensi sosial dan reperkusi negatif atas manusia dan planet yang disebabkan oleh semata-mata untuk mencapai tujuan maksimisasi keuntungan tidak diperhitungkan di sini. Argumennya, mereka hanya mendeskripsikan proses produksi itu apa adanya, dan itu bukan pekerjaan mereka untuk menjadi normatif jika utilitas privat konflik dengan utilitas sosial. Unit-unit produksi memang didefinisikan secara mantap dalam NL. Semua produksi barang dan jasa yang dihasilkan untuk pasar ekonomi formal diperhitungkan dalam sistem akunting nasional. Akan tetapi, banyak aktivitas produktif dalam masyarakat berada di luar sistem akunting nasional itu, termasuk di sini produksi pada tingkat rumah tangga, pertanian yang subsisten pada tingkat komunitas, pertukaran jasa yang berbasis suka-rela, dan produksi di sektor informal. Karena anggapan bahwa barang dan jasa yang dijual dan dibeli di pasar pada harga tertentu itu adalah kegiatan produktif, maka aneh jika memasak makanan di restoran dianggap produktif, sedang memasak makanan di rumah konsumtif.

CE memiliki pendekatan lebih luas tentang unit produksi ini, karena setiap orang dapat memproduksi sesuatu di mana saja, di rumah atau di perusahaan, dibayar atau tidak, formal atau informal, untuk pasar atau untuk diri sendiri. Produksi mencakup semua aktivitas yang berkontribusi terhadap pemeliharaan, kontinyuasi, dan perbaikan dunia kita untuk meningkatkan kualitas kehidupan bagi semua dalam cara yang berkelanjutan. Tidak hanya barang dan jasa dengan nilai tukar di pasar yang dianggap sebagai bagian dari produksi, tetapi juga barang dan jasa yang diproduksi untuk meningkatkan nilai gunanya. Misalnya, memproduksi makanan di rumah dapat memiliki nilai guna tinggi untuk mendukung kualitas kehidupan, tetapi makanan ini tidak memiliki nilai tukar di pasar. Sebaliknya, makanan-makanan yang tergolong "junk-food" (makanan 
sampah) yang menyebabkan sakit perut dan dijual di pasar memiliki nilai tukar, pada hal ia tidak menyumbang perbaikan kualitas hidup. Persaingan antar perusahaan membutuhkan investasi permanen untuk meningkatkan produktiitas modal dan tenaga kerja dan untuk mengintensifkan irama (rhytm) produksinya. Hasilnya, kecepatan eksploitasi sumberdaya untuk maksud produktif makin tinggi dibandingkan kecepatan waktu untuk memulihkan kondisi keseimbangan ekologisnya. Irama biologis alam dikalahkan oleh irama industri, karena itu sumberdaya alam semakin habis. Untuk menghentikan dan memperbaiki proses ini, CE mendorong investasi dan inovasi teknis yang memberi sumbangan kepada pemeliharaan dan perbaikan kondisi planet agar tercapai kualitas kehidupan lebih baik bagi semua melalui cara yang berkelanjutan. Namun, privatisasi dan introduksi prinsip pemasaran dan manajemen untuk meningkatkan produktivitas di sektor care (kesehatan, keperawatan, sekolah, dsb.) justru mengurangi nilai instrinsik yang penting bagi kualitas kehidupan. Sektor jasa care menjadi unit jasa layanan di pasar yang diperlakukan sama dengan komoditas yang bisa diperjualbelikan. Tenaga kerja di sektor itu akan kehilangan nilai intrinsik non-meneter, yaitu hilangnya afeksi tenaga kerja dalam bekerja. Afeksi ini dalam ketenagakerjaan bidang care adalah pekerjaan yang tidak bisa diganti (notsubstitutable). Tugas seorang perawat dalam menghibur dan menenangkan pasien tidak bisa digantikan oleh robot. Demikian tugas orang tua dalam membesarkan anaknya tidak bisa digantikan melalui percepatan oleh investasi teknis, karena tumbuh dan kembangnya anak terikat pada irama sosio-biologis yang memerlukan perhatian sehari-hari dalam kurun waktu tahunan, membutuhkan kesabaran, afeksi, tanggungjawab, komitmen, dan cinta kasih. Memang banyak tugas-tugas terkait dengan care bisa di-outsource-kan, tetapi tidak semuanya. Hal-hal yang terkait dengan urusan bagaimana menjalin hubungan baik antar manusia dan manusia dengan lingkungan dalam pekerjaan care tidak bisa di beli (dihargai dengan uang seperti barang dagangan). Globalisasi produksi dalam NL diatur dalam mekanisme sistem pasar bebas. CE berangkat dari visi yang holistik tentang sistem global, yang mencakup dimensi sosial dan sistem ekologis.

Tabel 5. Paradigma/Suposisi tentang Tenaga Kerja

\begin{tabular}{ll}
\multicolumn{1}{c}{ Neo-liberal } \\
$\begin{array}{l}\text { The value of labor is determined by supply } \\
\text { and demand on the labor market }\end{array}$ & $\begin{array}{l}\text { The value of labor is determined by its } \\
\text { contribution to both human and ecological } \\
\text { sustainable development }\end{array}$ \\
\hline $\begin{array}{l}\text { Trade Unions and governmental regulations } \\
\text { disturb the balance of the labor market }\end{array}$ & $\begin{array}{l}\text { Civil society regulates dialogue on human } \\
\text { resources in the process of sustainable social } \\
\text { development (participative democracy on } \\
\text { micro, meso, and macro level) }\end{array}$ \\
\hline Unpaid work has no value & $\begin{array}{l}\text { Unpaid work is just as valuable as paid work } \\
\text { for the economy }\end{array}$ \\
\hline $\begin{array}{l}\text { Unpaid work is not taken into acount in the } \\
\text { economic model which is used for } \\
\text { designing macroeconomic policy }\end{array}$ & $\begin{array}{l}\text { Both paid and unpaid work and their } \\
\text { interrelationship are taken into account in the } \\
\text { model for the conomy of care, and a sound } \\
\text { balance is pursue by macroeconomic policy }\end{array}$ \\
\hline
\end{tabular}

Dalam banyak negara volume tenaga kerja yang tak berbayar lebih besar daripada volume tenaga kerja yang berbayar di sektor formal dan sektor ekonomi lain secara bersama. NL dalam hal ini sama sekali mengabaikan pentingnya 
tenaga kerja tak berbayar, karena alasan sederhana bahwa tenaga kerja tak berbayar itu dipandang bukan hal yang langka. Hanya tenaga kerja yang muncul di pasar tenaga kerja yang diperhitungkan dalam sistem akunting nasional: nilai ekonomis tenaga kerja ditentukan oleh harga dari tenaga kerja (upah, gaji, imbalan) yang berlaku pada pasar tenaga kerja. Semakin langka tenaga kerja, semakin tinggi upah, gaji, atau imbalannya. Pada saat-saat angka pengangguran tinggi dan angka penawaran tenaga kerja melimpah, upah akan turun. Tenaga kerja tak berbayar di sini dipandang sebagai sumberdaya yang "over-abundant". Masyarakat dapat menggunaan tenaga kerja tak berbayar secara tak terbatas, selagi harga mencapai nol, dan karena itu dianggap tidak ada pengaruhnya dalam berfungsinya sistem ekonomi. Tenaga kerja tak berbayar masih tetap tidak nampak dalam sistem akuntinng nasional saat ini, termasuk dalam angka-angka statistik.

Dalam model CE nilai tenaga kerja ditentukan oleh kontribusinya terhadap proses pemeliharaan, kontinyuasi, dan perbaikan dunia ini dalam rangka memperbaiki kualitas kehidupan bagi semua dengan cara berkelanjutan. Pasar tenaga kerja diatur melalui proses-proses demokratis dan participatif di mana orang dapat berpartisipasi dalam dialog tentang bagaimana memperbaiki kualitas kehidupan untuk saat ini dan masa datang. Tenaga kerja tak berbayar dipandang senilai dengan tenaga kerja berbayar, kebijakan akan difokuskan pada pengendalian distribusi seimbang antara tenaga kerja berbayar dan tak berbayar untuk laki-laki maupun perempuan.

Tabel 6. Paradigma/Suposisi tentang Distribusi

\begin{tabular}{ll}
\hline \multicolumn{1}{c}{ Neo-liberal } & \multicolumn{1}{c}{ Caring Economic } \\
\hline $\begin{array}{l}\text { Distribution: market and governmental } \\
\text { regulation (redistribution) }\end{array}$ & $\begin{array}{l}\text { Distribution: market, government, } \\
\text { reciprocity, solidarity, mutual support, gifts, } \\
\text { recycling, LETS (Local Exchange Trading } \\
\text { Scheme) }\end{array}$ \\
\hline $\begin{array}{l}\text { Regulation through monetary system, bank } \\
\text { system and government }\end{array}$ & $\begin{array}{l}\text { Regulation also through LETS, } \\
\text { gender+generational relations (e.g. family, } \\
\text { friendship), virtual global exhange systems, } \\
\text { participative (gender) budgeting }\end{array}$ \\
\hline Value expressed in prices (monetary units) & $\begin{array}{l}\text { Value linked to comprehensive indicators, } \\
\text { which include the ecological footprint and } \\
\text { the Paid-Work-quote (PW-quote) }\end{array}$ \\
\hline $\begin{array}{l}\text { Scarcity: What has no price on the market, has } \\
\text { no value and is abundant and free for everyone } \\
\text { (such as air, trees, unpaid labor) }\end{array}$ & $\begin{array}{l}\text { Scarcity is a relative concept: The } \\
\text { perspective of human sustainable } \\
\text { development (contrbution to quality of life } \\
\text { for present and future generations) defines } \\
\text { what is scarce/abundat }\end{array}$ \\
\hline
\end{tabular}

NL memandang pemerintah, pasar, dan sistem perbankan berperan krusial sebagai regulator distribusi pendapatan, barang dan jasa di masyarakat. CE menambahkan sistem regulasi yang tidak nampak dalam sistem regulasi yang dominan, yaitu memasukkan regulasi sosial berbasis gender dan generasional yang mengatur distribusi waktu, uang, dan properti, dan terhadap kehadiran sistem pertukaran informasi dan sumberdaya global secara virtual (melalui dunia maya).

Pasar dan pemerintah dalam NL memegang peran utama dalam distribusi sumberdaya, sedangkan CE memandang distribusi lebih komprehensif, termasuk 
pula sirkuit pertukaran non-market, komunikasi, dan distribusi, seperti pertukaran nilai berbasis solidaritas, resiprositas, atau komitmen dan tanggung jawab sosial. Sistem ini tidak ada dalam kosa kata NL, walaupun mereka ada dalam ekonomi riil dan dalam jumlah besar memiliki dampak pada kualitas hidup dan kehidupan sosial. Sistem sirkulasi dalam CE mencakup saling bantu antar tetangga, pengasuhan yang tak berbayar untuk keluarga dan teman, pekerja relawan pada tingkat komunitas, daur ulang dan pertukaran pakaian bekas lintas tetangga, LETS (Local Exchange Trading Scheme), sistem pertukaran bebas online, pelatihan gratis dalam kelompok penggemar olah raga, Palang Merah, dan masih banyak lagi aktivitas yang tidak termasuk dalam saluran distribusi formal yang dilakukan oleh pasar dan pemerintah. Semua bentuk distribusi barang dan jasa tersebut memainkan peran krusial dalam ekonomi riil. Bahkan pada masa perang, krisis, hiperinflasi atau runtuhnya sistem perbankan - ketika pasar tidak lagi mampu bekerja - distribusi informal tersebut terus jalan, dan mungkin semakin kuat. Memang bentuk-bentuk distribusi itu ada di luar fokus model NL dan dianggap irrasional menurut paham homo economicus, tetapi praktik pertukaran yang berbasis solidaritas itulah dalam CE justru yang paling rasional.

Nilai dalam NL dinyatakan dalam satuan moneter (harga). Dalam CE nilai adalah konsep yang lebih luas, yang terkait dengan footpint ekologis dan kontribusi orang-orang yang berbayar dan tak berbayar pada kehidupan yang berkelanjutan. Artinya, CE melekat di dalam sistem ekologis dan dalam ekonomi riil.

Kelangkaan adalah salah satu konsep kunci untuk menjelaskan nilai ekonomi dalam teori NL. Harga menyatakan nilai ekonomi barang dan jasa dalam permintaan dan penawaran. Semakin langka produk (permintaan tinggi, penawaran rendah) semakin tinggi harganya. Produk yang tidak memiliki harga di pasar bisa jadi sangat berguna tetapi ia dianggap bukan produk langka bagi NL, seperti melimpahnya udara yang kita hirup untuk bernafas. Udara hanya menjadi langka ketika untuk mendapatkan udara bersih atau segar kita harus membeli tabung oksigen yang diproduksi oleh pabrik. Udara, dengan demikian akan menjadi produk pasar yang menarik dan akan menyumbang pertumbuhan ekonomi. Alam itu sendiri, udara sehat, air bersih, dengan ikan-ikan berenang di sungai, panorama lingkungan yang indah, atau bio-difersitas tidak muncul sebagai produk di pasar. Karena itu mereka tidak punya harga dan dianggap sebagai "over-abundant". Bahkan spesies yang menghadapi kepunahan - dalam bahasa ekonomi - bukanlah barang langka, dan kepunahannya tidak ada konsekuensinya bagi pertumbuhan ekonomi, selama mereka bukan (secara potensial) produk di pasar.

CE mendefisisikan langka atau melimpah dari sudut pembangunan manusia yang berkelanjutan. Kriteria yang digunakan bukan harga pasar, tetapi pada kontribusinya terhadap kualitas kehidupan untuk generasi saat ini dan mendatang. Model CE berbasis pendekatan komprehensif dan fokus pada suatu keseimbangan yang berkelanjutan antara dimensi-dimensi manusia, ekologis, dan ekonomis masyarakat. Perilaku tentang caring human being dibuat visibel dan dipromosikan sebagai suatu basis eksplisit bagi kebijakan dan praktik sosioekonomi. Suatu masyarakat yang caring kurang membutuhkan aturan, hukum, dan kontrol represif, yang diiringi dengan perilaku bertanggunng jawab 
dan mengatur dirinya sendiri menuju suatu masyarakat manusia yang berkelanjutan (human sustainable society).

\section{Model Dasar Economy of Care (EoC)}

Model dasar Economy of Care (EoC) adalah suatu pendekatan yang membuat "care" menjadi titik awal dan kekuatan pendorong ekonomi. Ini bukan tentang privatisasi dan pemasaran sektor care. EoC adalah pendekatan holistik yang berpusat pada manusia dan lingkungan ekonomi yang bersahabat. Saling berhubungan dan bergantung antara laki-laki dan perempuan dalam segala diversitasnya dan antara orang-orang dan lingkungan alam adalah sentral dari EoC. kehidupan:

EoC hendak menggapai suatu keseimbangan dari tiga sistem dasar

(a) Sistem ekologis (ecological system)

(b) Sistem generasi, atau sistem untuk menggenerasi kehidupan manusia (generating system or system to generate human life)

(c) Sistem produksi (production system)

Sepanjang sejarah, ada tiga sistem regulasi penting yang terkristalisasi, untuk mencapai keseimbangan antar tiga sistem dasar di atas:

(a) Sistem sirkulasi (circulation system)

(b) Sistem politik/legal (political/legal system)

(c) Sistem masyarakat sipil (system of civil society)

Secara historis pada komunitas manusia "self-sustaining" (yang menopang sendiri kehidupannya) ketiga sistem dasar kehidupan tersebut trintegrasi dalam satu ekonomi subsisten komprehensif. Selama berabad-abad sistem itu kemudian tumbuh terpisah karena perkembangan kekuatan produksi, spesialisasi, pembagian lapangan kerja, dan meningkatnya hubungan pertukaran.

Industrialisasi telah memisahkan rumah dan tempat bekerja. Pabrik yang menerapkan sistem produksi masal telah memisahkan kehidupan pribadi atau keluarga (di rumah) dan kehidupan di pabrik (tempat kerja). Keadaan ini melahirkan apa yang disebut "house-wife/breadwinners model" (ibu-rumah tangga pencari nafkah untuk menyambung hidup) yang tinggal di rumah sebagai tenaga kerja tak berbayar, sedangkan suaminya bekerja di pabrik sebagai tenaga kerja berbayar.

Dalam era teknologi komunikasi dan informasi sekarang, terjadi fenomena menuju pengintegrasian kembali aktivitas ekonomi ke "rumah", pekerjaan kantor di bawa pulang, belanja dan transaksi perbankan bisa dilakukan di rumah lewat daring (online). Koneksi lewat internet telah mengubah transaksi komunikasi dan sirkulasi ekonomi secara global.

Integrasi yang sekarang kita saksikan dalam kehidupan nyata dalam model dasar EoC disintesakan sebagai Gambar 5 berikut. 


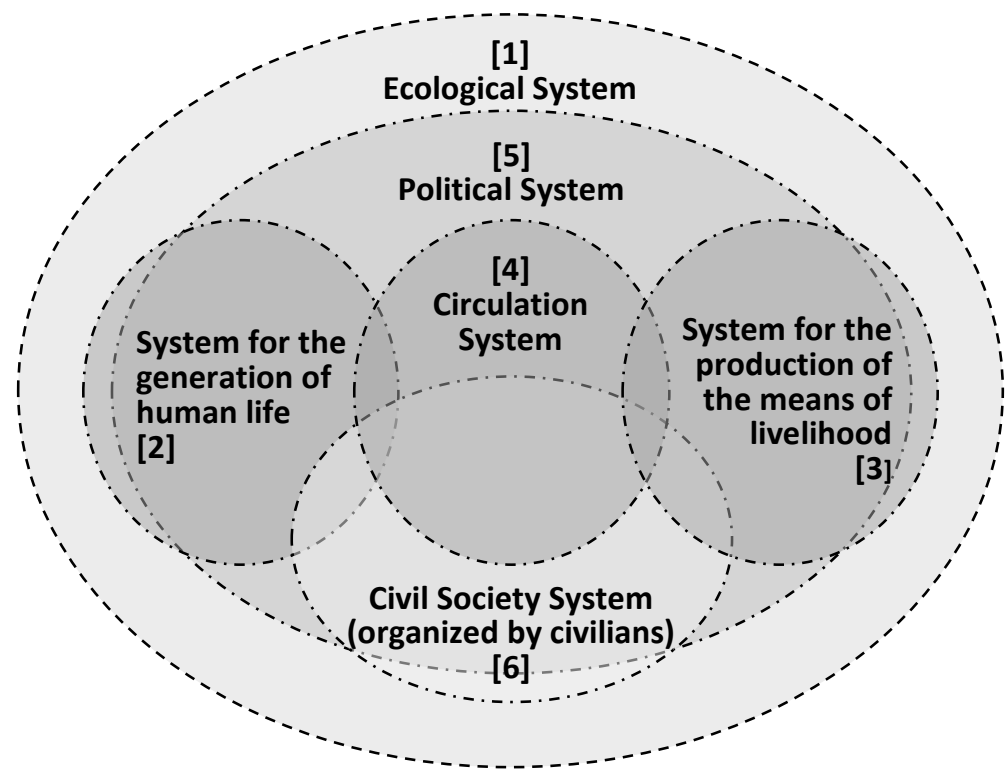

Basic Life Systems: [1], [2], [3] Regulation Systems: [4], [5], [6]

Gambar 5. Model dasar Economy of Care (EoC)

(Adaptasi dari van Osch, 2013, hlm. 17 \& 19)

Ada enam lingkungan (spheres) dalam model dasar EoC. Sistem kehidupan dasar berada pada lingkungan [1], [2], dan [3]. Sistem regulasi berada pada lingkungan [4], [5], dan [6]. Posisi saling overlapped dan garis batas putusputus itu menunjukkan bahwa keenam sistem itu bukanlah sistem yang tertutup (closed system). Masing-masing berinteraksi sesuai dengan posisi dan peran utamanya.

Tiap sistem kehidupan dasar memiliki logikanya sendiri dalam konteks EoC. Kriteria dan keterkaitan logis antar tiga sistem kehidupan dasar dirangkum dalam Tabel 7 berikut.

Tabel 7. Kriteria dan keterkaitan logis antar 3 sistem kehidupan dasar

\begin{tabular}{llll}
\hline Criterion & \multicolumn{1}{c}{ Ecological System } & \multicolumn{1}{c}{ Generating System } & \multicolumn{1}{c}{ Production System } \\
\hline Time/Rh & - Biological rhytm & - Socio-biological rhytm & - Industrial rhytm \\
ytm & (day/night; water/sun) & - Daily reproduction & (technological \\
& - Season bound & - Generational & development) \\
& - Reproduction cycles of \\
fauna and flora, etc. & $\begin{array}{c}\text { reproduction } \\
\text { - Emotional/cultural } \\
\text { reproduction }\end{array}$ & $\begin{array}{l}\text { - Digital rhytm (ICT } \\
\text { development) }\end{array}$ \\
\hline Relations & - Natural laws & - Kinship relations & - Production relations \\
& - Biodiversity & - Gender relations & - Property relations \\
& - Relations between & - Generational relations & - Social Class relations \\
& fauna, flora, and & & \\
& humans & & \\
\hline Sources & - Sun, water, fire, earth & - Subsistence means & - Raw materials \\
& - Season bound natural & - (Care) Labor & - Labor \\
& production & - Use values (food, clean & - Production means \\
& - Replaceable and non- & clothes, clean house, & - Financing means \\
& replaceable natural & etc.) & \\
& resources & - Use capital (house, car, & \\
& & PC, TV, domestic & \\
& & apparatus, etc.) & \\
& & - Savings &
\end{tabular}




\begin{tabular}{llll}
\hline Threats & - Exhaustion of natural & - Lack of means for & - Lack of raw materials \\
resources (peak oil & survival (hunger, & (industrial rhytm higher \\
crisis) & poverty) & that biological rhytm - \\
- Environmental pollution & - Lack of care (illness) & increasing prices) \\
and degradation & - Impoverishment & - Surplus/lack of labor \\
(pollution of air, water, & - Disintegration of & forces (production \\
loss of biodiversity, & communities and & system not balanced \\
etc.) & kinship structures & with generating system: \\
& & unemployment/stressed \\
& & labor market) \\
\hline
\end{tabular}

Sumber: Adaptasi dari van Osch, 2013, hlm. 18

Salah satu contoh keterkaitan antara sistem generating dan sistem produksi adalah relasi berbasis gender antara distribusi pendapatan (dalam sistem produksi) dan tenaga kerja tak berbayar (dalam sistem generating). Ada kaitan genderspesifik antara care-receiving dan care-giving. Selama siklus caring itu, perempuan memberi care lebih banyak daripada yang diterima, sedangkan lakilaki menerima lebih banyak daripada yang ia diberikan.

Sistem regulasi mengatur interaksi antar tiga sistem dasar kehidupan. Sirkulasi yang dimaksud lebih luas cakupannya, tidak hanya sirkulasi yang berlangsung melalui pasar (dalam paham NL), tetapi mencakup pula sirkulasi yang berlangsung dalam mekanisme pertukaran berbasis solidaritas, LETS, resiprositas, dan mekanisme distribusi lainnya.

Sistem politik (yang diwakili oleh pemerintah) bertugas mengatur ekonomi, khususnya jika terjadi ketidak-seimbangan. Regulasi umum yang dilakukan pemerintah antara lain dalam distribusi pendapatan (misalnya melalui sistem perpajakan atau kebijakan fiskal), kebijakan pasar tenaga kerja, kebijakan upah, kebijakan harga, penyediaan barang dan jasa publik (pendidikan, kesehatan, pertahanan, keamanan, bencana alam, dsb.), menyusun produk legislasi dan penegakan hukum.

Selama ini ada dua pendekatan yang mendominasi ekonomi pasar di di negara industrialis barat:

(a) pendekatan pro-pemerintah (misalnya: Keynesian dan Institusionalis)

(b) pendekatan laissez-faire yang pro-pasar (misalnya: Monetaris dan Neoliberalis).

Namun, kedua pendekatan itu tidak bisa memecahkan masalah ketidakseimbangan fundamental yang terjadi pada interaksi antar tiga sistem kehidupan dasar, sebab, ketiga sistem itu pada dasarnya berada di luar lingkup pemikiran ekonomi dua pendekatan di atas.

Karena itu, jika pemerintah (melalui kebijakan politik dan hukumnya) maupun pasar tidak bisa mengatasi ketidak-seimbangan itu, maka sistem masyarakat sipil (civil society system) yang akan merespon dan mengambil inisiatif untuk mengembalikan keseimbangan antar tiga sistem dasar kehidupan. Asosiasi tenaga kerja yang membela penindasan terhadap kaum buruh, organisasi wanita yang menyerukan kesetaraan gender dalam kehidupan rumah tangga atau ranah publik, organisasi wahana lingkungan yang menyerukan perlindungan dan penggunaan sumberdaya yang berkelanjutan, berbagai organisasi relawan yang memperjuangkan hak-hak komunitas difabel, komunitas miskin, adalah contoh nyata dari peran sistem masyarakat sipil. Sistem ini memilki fungsi dan peran penting dalam pemulihan keseimbangan antar tiga sistem kehidupan dasar. 


\section{Kebijakan Makroekonomi berbasis EoC}

EoC niscaya bisa dijadikan basis kebijakan makroekonomi, dengan asumsi sejumlah kondisi eksistensial berikut (adaptasi dari van Osch, 2013, hlm. 20):

(a) manusia hidup mengimbangi lingkungan alamnya;

(b) mereka kurang bergantung pada uang untuk membangun suatu kehidupan;

(c) perencanaan tata-ruang dan perumahan mempertimbangan diversitas gaya hidup dan ditujukan untuk meningkatkan self-sufficiency-nya;

(d) diversitas kultural adalah sumberdaya dari kualitas kehidupan;

(e) manusia memiliki waktu luang lebih banyak untuk sesama, menikmati lingkungan alam, dan pengembangan individual;

(f) hak untuk menerima dan memberi care dijamin bagi setiap orang;

(g) pekerjaan yang tak berbayar dan yang berbayar dinilai sama;

(h) masyarakat terorganisasi sedemikian rupa sehingga tercapai keseimbangan antara pekerjaan dan kehidupan bagi tiap orang secara individual dan bagi masyarakat secara keseluruhan.

Kebijakan makroekonomi yang diterapkan pemerintah saat ini harus disesuaikan dengan asumsi-asumsi itu untuk bisa mencapai EoC.

Penyesuaian ini tidak hanya untuk pertumbuhan ekonomi saja, tetapi juga untuk mewujudkan kemakmuran sosial dan lingkungan alamnya. Karena, pembangunan sosial yang berkelanjutan menjadi tujuan utama kebijakan makroekonomi dalam EoC. Pendapatan per kapita menjadi kurang penting, dan jumlah uang yang dibelanjakan konsumen kurang relevan dalam makroekonomi. Sebaliknya, ESU (Environmental Space Used) per kapita dan distribusi tenaga kerja yang berbayar dan yang tak berbayar menjadi faktor kunci dalam kebijakan berbasis EoC. Kebijakan pembangunan berbasis EoC membutuhkan SNA (System of National Accounts) yang mencakup tiga dimensi dan indikator baru (adaptasi dari van Osch, 2013, hlm. 21):

(1) Kemakmuran alam (natural wealth), yang bisa diukur dengan ESU.

(2) Kemakmuran sosial (social wealth), harus memasukkan relasi antara tenaga kerja berbayar dan tak berbayar per kapita (bisa diukur dengan PW-quote).

(3) Kemakmuran ekonomi (economic wealth) mengukur pendapatan per kapita.

Bagaimana kaitannya dengan tiga sistem dasar kehidupan? Berikut ini pokok-pokok kebijakan makro-ekonomi EoC dalam konteks sistem kehidupan dasar (adaptasi dari van Osch, 2013, hlm. 21-22):

(1) Fungsi konsumsi dalam model makro-ekonomi diganti dengan fungsi spasi lingkungan (ESU). Pengeluaran-pengeluaran konsumtif akan dinyatakan dalam satuan ESU, bukan dolar, euro, atau satuan mata uang lainnya.

(2) ESU adalah unit akunting yang bersifat global, yang menghubungkan ekonomi setiap negara dengan sistem lingkungan global.

(3) PW-quote mengukur hubungan antara ekonomi yang berbayar dan tak berbayar pada semua tingkat (individu, komunitas, sektor, nasional, regional, dan global).

(4) Siklus dan ritme (time-rhytms) dari ekosistem, regenerasi dan produksi dimasukkan dalam perhitungan. Ritme industri berpacu bersama ritme kehidupan manusia dan ritme biologis ekosistem. Ritme kehidupan manusia mengacu pada ritme sosial-biologis sehari-hari, generasionalitas, emosional, dan reproduksi kultural. Setiap orang - laki-laki dan perempuan - mampu membuat keseimbangan antara care dan work.

(5) Ada suatu sistem akunting pemerintah dan perusahaan yang dapat melacak aliran uang dan mengakses dampaknya bagi laki-laki dan perempuan pada semua diversitasnya, dan bagi lingkungan, sistem yang transparan dan terakses untuk setiap orang melalui internet.

(6) Pemerintah (pusat dan daerah) dan perusahaan menyajikan neraca tahunan komprehensif, tidak hanya data finansial, tetapi juga data sosial dan 
ekologisnya. Misalnya, suatu negara punya utang ekologis pada dunia jika ecological footprint-nya per kapita di negara itu lebih tinggi daripada sustainable footprint perkapita (= fair-planet-share).

(7) Ada GSA (Global Accounting System) yang memvisualisasikan kemakmuran alam, sosial, dan ekonomi, termasuk dampak ketidak-seimbangan pembangunan lintas-batas (transboundary impacts of unbalanced development). Negara-negara dengan utang ekologis (rata-rata ESU per kapita di atas "fair-planet-share") harus memberi kompensasi kepada negaranegara yang ESU per kapita-nya lebih rendah daripada "fair-planet-share". Jika PW-quote untuk pekerja anak-anak di sektor tertentu menunjukkan bahwa perdagangan luar negeri berbasis tenaga kerja anak, maka hal ini memunculkan utang sosial pada neraca perdagangan negara pengimpor barang. Di sini, utang sosial itu harus dibayar untuk memperbaiki keberlanjutan sosial (misalnya pendidikan dan kesehatan) di negara-negara miskin. Hal ini bisa dilakukan melalui kesepakatan multilateral, di mana negara-negara yang terlibat membangun suatu sistem memeratakan kemakmuran alam, sosial, dan ekonomi.

Berdasarkan telaah tiga rujukan di atas bisa disimpulkan bahwa caring economics adalah sistem ekonomi baru yang bertolak dari paradigma berpikir dan bertindak untuk tujuan peningkatan kualitas kehidupan manusia dan lingkungan secara holistik dan berkelanjutan.

\section{CARING ECONOMICS DALAM CONTEXTUAL ECONOMICS}

Aktivitas ekonomi dalam relita selalu berada di dalam konteks sosial dan lingkungan. Neva R. Goodwin, et al. (2014) ${ }^{\mathbf{5}}$ menempatkan caring economics sebagai bagian dan karakter utama model ekonomi kontekstual. Konstruksi model kontekstual dalam Gambar 6 berikut menurut Goodwin et al. menjadi model alternatif dari model dasar ekonomi neo-klasik.

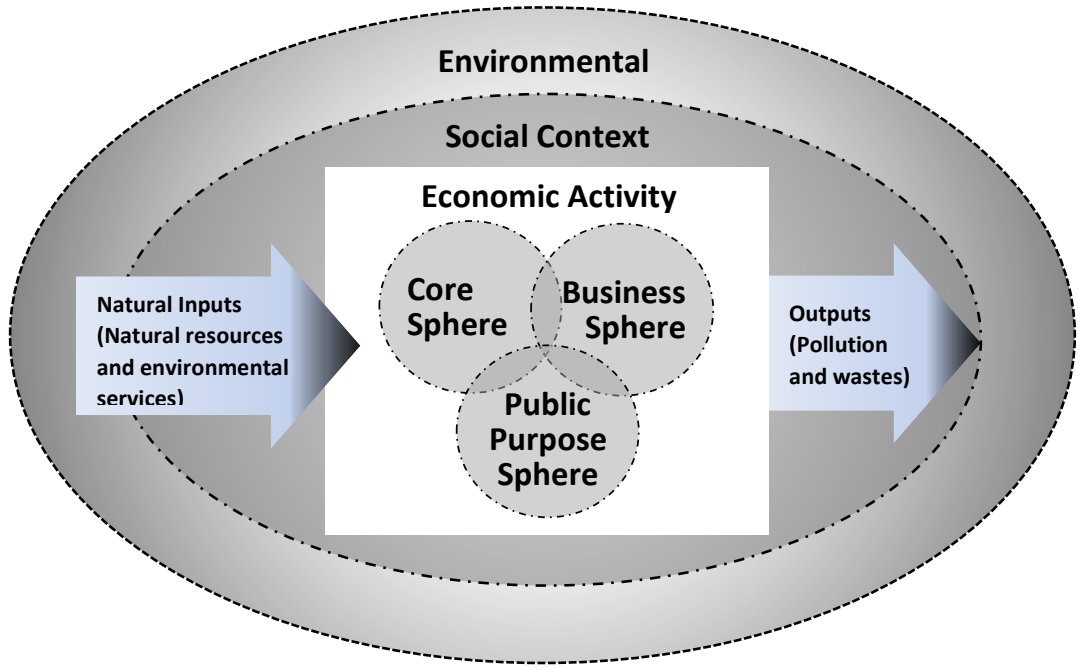

Gambar 6. Aktivitas ekonomi dalam konteks sosial dan lingkungan Sumber: Goodwin, et al., 2014, hlm. 63

Mereka mengklaim bahwa model Gambar 6 itu lebih inklusif dan realistik jika dibandingkan dengan model neo-klasik - yang dikenal dengan Circular Flow Diagram (lihat hlm. 62-63). Inklusif dan realistiknya identik dengan "reframing the domain of economics" dari Eisler (Gambar 3). Konteks lingkungan

5 Dalam "Principles of Economics in Context" (Marmonk, NY: M.E. Sharpe. 2014), Seksi 2.2 The Contextual Model, dan 3.4 Self-Interest, Altruism, and Common Good, hlm. 63-72 \& 185-189. 
(environmental context) sama dengan lingkungan [1] dalam van Osch (Gambar 5), karena ... [The] environmental context for economic activities includes the built environment as well as the natural world, but its fundamental process are ecological (Goodwin et al., hlm. 63). Dalam konteks lingkungan, aktivitas ekonomi memasukkan inputs sumber-sumber daya alam ke dalam tiga lingkungan (spheres: Core, Business, Public Purpose) dan mengubahnya menjadi barang dan jasa yang dibutuhkan manusia (outputs). Dalam proses transformasi itu, polusi dan sampah yang dihasilkan ternyata tidak hanya sebagai eksternalitas negatif, tetapi juga menjadi eksternalitas positif. Eksternalitas positif dari adanya polusi dan sampah mendorong manusia untuk care terhadap lingkungannya, misalnya daur ulang sampah, dan upaya perbaikan lahan dan hutan agar tetap atau semakin subur dan produktif.

Ekonomi juga beroperasi dalam konteks sosial, yang dibangun dan dilaksanakan oleh manusia, meski mereka tidak menyadari bahwa mereka mendesainnya sebagai suatu sistem. Konteks sosial mencakup sejarah, politik, budaya, etika, dan motivasi manusia yang lain. Konteks sosial ini menentukan apa saja yang bisa diterima menjadi aktivitas ekonomi. Misalnya, kita tidak mengijinkan perdagangan organ manusia atau narkoba. Aspek-aspek penting dalam konteks sosial, seperti kepercayaan, kejujuran, norma, dan aturan atau hukum, ikut menentukan terwujudnya aktivitas ekonomi.

Tiga lingkungan (spheres) di dalam konteks aktivitas ekonomi diklasifikasikan juga sebagai tiga pelaku utama ekonomi. Lingkungan pertama dikategorikan sebagai "core sphere" atau inti, terdiri dari rumah tangga, keluarga, dan komunitas. Lingkungan kedua dikategorikan sebagai "business sphere" atau lingkungan bisnis, mencakup firma, badan usaha, atau perusahaan, yang memproduksi barang dan jasa untuk memperoleh laba, dan organisasi usaha lain, misalnya koperasi (cooperatives) yang lebih mengutamakan manfaat (benefits) daripada laba (profits). Lingkungan ketiga dikategorikan sebagai "public purpose sphere" atau lingkungan yang menyediakan kepentingan publik, mencakup badan atau agen pemerintah, dan berbagai organisasi nirlaba (lembaga-lembaga amal, keagamaan, asosiasi profesi, Bank Dunia dan PBB) yang bertujuan meningkatkan kesejahteraan manusia dan lingkungannya. Individu dalam konteks aktivitas ekonomi dalam tiga lingkungan itu bisa bergerak dari lingkungan satu ke lingkungan yang lain. Misalnya, seorang wanita yang biasanya sebagai ibu rumah tangga (core sphere) bisa menjadi wanita karier di perusahaan (business sphere) dan bisa pula meluangkan waktu dan tenaganya menjadi pengurus suatu Yayasan sebuah Panti Asuhan (public purpose sphere).

Altruisme oleh Goodwin et al. (hlm. 185-187) di posisikan sebagai lawan dari "pure self-interest", yaitu kepedulian terhadap kesejahteraan orang lain, tanpa memikirkan dirinya sendiri (concern for the well-being of others, with no thought about oneself). Namun, dalam realita, perilaku manusia dalam memenuhi kebutuhan ekonominya tidak pernah betul-betul "self-interst" dan tidak sepenuhnya "altruistik", tetapi campuran keduanya. Dalam hal ini akan ditentukan oleh sejauh mana perilaku manusia itu termotivasi untuk meningkatkan pencapaian "common good" (kemaslahatan umum, atau kesejahteraan masyrakat umum). Jika seseorang melakukan aktivitas ekonomi untuk kepentingan terwujudnya kesejahteraan umum, sedang ia sendiri hanya menikmati sebagian daripadanya, maka ia cenderung altruistik. Dalam ekonomi kontekstual, model 
perilaku ekonomi manusia altruistik sosial mayoritas ada pada public purpose sphere. Sedangkan altruistik individual ada pada core sphere.

\section{CARING ECONOMICS DALAM KONTEKS EKONOMI PANCASILA \& UUD 1945}

Apa relevansi dan pentingnya caring economics dalam konteks Ekonomi Pancasila (selanjutnya disingkat: EP) dan UUD 1945 (khususnya Pasal 33 dan 34)?

Relevansi yang dimaksud di sini adalah keterkaitan logis antara caring economics dan EP (sebagai landasan filosofis) dan UUD 1945 (sebagai landasan konstitusional) perekonomian nasional. Pentingnya analisis relevansi ini adalah untuk menyawab pertanyaan: Apakah caring economics itu layak menjadi acuan dalam pengembangan dan penerapan kurikulum pembelajaran ekonomi yang berkarakter EP dan UUD 1945?

Analisis relevansi di sini tidak akan menelaah dan mengulang kembali risalah tentang wacana dan polemik EP seperti yang sudah dilakukan oleh Tarli Nugroho (2010b), dan pokok-pokok pikiran, kritik, serta formulasi EP dan Pasal 33 dan 34, UUD 1945 yang sudah dikemukakan oleh Emil Salim, Mubyarto, SriEdi Swasono, Dawam Rahardjo, Ginanjar Kartasasmita, dan Witjaksono (lihat Daftar Pustaka dalam artikel ini).

Analisis relevansi saya lakukan secara pragmatis dengan menilik lebih seksama bunyi pasal dan ayat hasil amandemen ke empat yang dikutip dalam Tabel 8 berikut dikaitkan dengan konsep, prinsip, paradigma, teori, dan kebijakan ekonomi menurut caring economics.

Tabel 8. Kutipan Pasal 33 dan 34 UUD 1945 Amandemen IV (10 Agustus 2002)

BAB XIV
PEREKONOMIAN NASIONAL DAN KESEJAHTERAAN SOSIAL
Pasal 33
(1) Perekonomian disusun sebagai usaha bersama berdasar atas asas kekeluargaan.
(2) Cabang-cabang produksi yang penting bagi negara dan yang menguasai hajat hidup
orang banyak dikuasai oleh negara.
(3) Bumi dan air dan kekayaan alam yang terkandung di dalamnya dikuasai oleh negara
dan dipergunakan untuk sebesar-besar kemakmuran rakyat.
(4) Perekonomian nasional diselenggarakan berdasar atas demokrasi ekonomi dengan
prinsip keadilan, kebersamaan, efisiensi berkeadilan, berkelanjutan, berwawasan
lingkungan, kemandirian, serta dengan menjaga keseimbangan kemajuan dan kesatuan
ekonomi nasional.
(5) Ketentuan lebih lanjut mengenai pelaksanaan pasal ini diatur dalam undang-undang.
(1) Fakir miskin dan anak-anak terlantar dipelihara oleh negara.
(2) Negara mengembangkan sistem jaminan sosial bagi seluruh rakyat dan
memberdayakan masyarakat yang lemah dan tidak mampu sesuai dengan martabat
kemanusiaan.
(3) Negara bertanggung jawab atas penyediaan faslitas pelayanan kesehatan dan faslitas
pelayanan umum yang layak.
(4) Ketentuan lebih lanjut mengenai pelaksanaan pasal ini diatur dalam undang-undang.

Judul "Perekonomian Nasional dan Kesejahteraan Sosial" dijabarkan ke dalam dua pasal, pasal 33 tentang "perekonomian nasional", dan pasal 34 tentang "kesejahteraan sosial". 
Analisis pragmatis tentang relevansi konsep, prinsip, paradigma, teori, dan kebijakan ekonomi menurut caring economics dalam rujukan utama dan pelengkap dengan bunyi ayat dalam pasal 33 dan 34 disintesakan sebagai berikut:

(1) Pasal 33:

a) Ayat 1, relevan dan sepaham dengan paradigma kemitraan Eisler (Gambar 4).

b) Ayat 2 dan 3, relevan dan sepaham dengan konsep sistem ekonomi yang "fundamentally pro-social being" (Singer et al. Tabel 1); transformasi (r)evolusi global menuju "sustainbale quality of life", (Hunziker-Ebtener Gambar 2); dan dan "economy care: paradigm shift from homoeconomicus to caring human being" (van Osch Tabel 2 - 6, Gambar 5).

c) Ayat 4, relevan dan sepaham dengan Eisler (Gambar 3 \& 4); Hunziker-Ebtener (Gambar 2); van Osch (Tabel 2 - 6, Gambar 5); dan Goodwin et al. (Gambar 6).

(2) Pasal 34:

Ayat 1, 2, dan 3, relevan dan sepaham dengan altruisme dan kompasionat (Singer et al. \& Eisler); EoC dalam kebijakan makroekonomi (van Osch); dan dengan "economics in the environment and social contexts" (Goodwin et al.).

\section{PENUTUP}

Kelayakan Caring Economics menjadi Karakter Ekonomi dan Pendidikan Ekonomi Nasional

Apakah caring economics itu layak menjadi acuan dalam pengembangan dan penerapan kurikulum pembelajaran ekonomi yang berkarakter EP dan UUD 1945 ?

Secara pragmatis ya. Namun, sudah barang tentu tidak bisa disimpulkan bahwa EP sama dengan CE (Caring Economics). Untuk saat ini, menurut hemat saya, yang bisa ditarik kesimpulannya adalah bahwa EP yang dijabarkan lebih lanjut pada Pasal 33 dan 34 itu memang sarat dengan karakter CE, yaitu mengedepankan kepentingan semua pihak berdasarkan semangat altruisme dan kompasionat dalam relasi sesama manusia dan manusia dengan lingkungannya menuju sasaran akhir pembangunan ekonomi nasional, yaitu meningkatkan kesejahteraan dan kemakmuran untuk mewujudkan kualitas kehidupan yang berkelanjutan (well-being and prosperity for sustainable quality of life).

Dengan demikian, jika kita menghendaki agar pendidikan ekonomi secara nasional memiliki karakter $\mathrm{CE}$, tidak diragukan lagi. Implikasinya, perlu komitmen dan kesungguhan dalam memikirkan dan menerapkan CE itu ke dalam situasi dan kondisi yang sementara ini saya rumuskan dalam rekomendasi dan tindak lanjut berikut.

\section{Rekomendasi dan Tindak Lanjut}

\section{Penjabaran operasional Pasal 33 dan 34 UUD 1945 (Amandemen IV, 2002)}

Penjabaran secara operasional pasal 33 dan 34 UUD 1945 perlu segera dilakukan. Beberapa bahan kajian dan acuan untuk penjabaran sudah tersedia cukup banyak dan layak. Dokumen publikasi yang disebutkan dalam daftar pustaka artikel ini, terutama Mubyarto (2000 \& 2004a), Mubyarto \& Santosa 
(2004), Swasono (2009, 2010 \& 2012a), dan Witjaksono (2013), dapat digunakan sebagai langkah awal tindak lanjut. Dalam kesempatan ini saya menghimbau kepada partisipan yang hadir dalam seminar (guru, mahasiswa, dan dosen) untuk memulai mengkaji kembali rujukan-rujukan tersebut di atas.

\section{Pengkajian Kurikulum, Perangkat Pembelajaran, dan Praktik Pembelajaran Ekonomi di Sekolah}

Dengan asumsi rekomendasi di atas sudah mulai dilaksanakan, selanjutnya adalah mencermati secara kritis kurikulum, perangkat dan praktik pembelajaran ekonomi di sekolah. Pengkajian secara cermat perlu dilakukan untuk menjawab pertanyaan dasar tentang kesesuaian tujuan (learning objectives), materi (contents), dan sumber-sumber belajar (learning resources) dengan karakteristik CE. Hasil analisis isi dari rujukan (utama dan pelengkap) yang dipaparkan dalam artikel ini, khususnya paradigma dan suposisi van Osch (Tabel 2 s.d. 6) sangat disarankan untuk diintroduksi ke dalam pokok bahasan terkait. Tindak lanjut dari kajian ini bisa dikembangkan lagi, misalnya dalam forum MGMP (Musyawarah Guru Mata Pelajaran) Ekonomi. Untuk mahasiswa dan dosen program studi Pendidikan Ekonomi bisa melalui riset pengembangan pembelajaran ekonomi yang berbasis "caring".

\section{Kampanye Gerakan "Caring Economics" di Lingkungan Perguruan Tinggi}

Gerakan CE melalui kampanye di perguruan tinggi, salah satunya melalui NCEE 2016, tetapi, harus ditindaklanjuti dengan kegiatan akademik lainnya. Dalam hal ini, disarankan kepada program studi S1, S2, dan S3 Pendidikan Ekonomi untuk bersama-sama memikirkan dan mencari alternatif kampanye itu secara terpadu, misalnya introduksi dalam perkuliahan yang dilanjutkan dengan riset pengembangan untuk menghasilkan berbagai format dan model pembelajaran ekonomi berbasis "caring". Kampanye di sini bisa diperluas jangkauan sasarannya dengan mengajak keterlibatan secara aktif konstruktif (kolaboratif) masyarakat umum, pemerintah, dan gerakan ekonomi rakyat yang sudah eksis (seperti yang dilakukan oleh PUSTEP/PSP UGM, Yogyakarta).

\section{DAFTAR RUJUKAN}

Ariana, S.M. \& Mirabela, P.A. (2013). "Economy, Economics, Economic, Economical." https://ideas.repec.org/a/ora/journl/v1y2013i1p403-412.html

Babbie, E. (2011). The Basic of Social Research, 5th Ed. Belmont, CA: Wadsworth, Cengage Learning.

Baker, L.M. (2008). "Unobtrusive Research." In L.A. Given (Ed.) The SAGE Encyclopedia of Qalitative Research Methods, Vol.1 \& 2. Los Angeles, CA: SAGE Publishing, Inc. Pp. 904-906.

Becker, G.S. (1965). A Theory of the Allocation of Time. The Economic Journal, September 1965, hlm. 493-517.

Berg, B.L. (2001). Qualitative Research Methods for the Social Sciences, 4th Ed. Boston, MA: Allyn \& Bacon.

Bryman, A. (2012). Social Research Methods, 4th Edition. Oxford: Oxford University Press. 
Eisler, R. (2007). The Real Wealth of Nations: Creating a Caring Economy. San Francisco, CA: Berret-Koehler.

Eisler, R. (2013). Building a Caring Economy and Society: Beyond Capitalism, Socialism, and other Old Isms. Cadmus, 1(6), 49-65.

Goodwin, N.R., Harris, J., Nelson, J.A., Roach, B. \& Torras, M. (2014). Principles of Economics in Context. New York: M.E. Sharpe.

Hawk, T.F. (2011). Book Review of "The Real Wealth of Nations: Creating a Caring Economics". Academy of Management Learning \& Education, December 2011, 739-743.

Heckman, J. (2014). "Introduction to A Theory of the allocation of Time by Gary Becker." IZA Discussion Paper No. 8424. August 2014.

Hunziker-Ebtener, A. (2015). "Profit with a Purpose." Dalam T. Singer \& M. Richard (Eds.) Caring Economics: Conversation on Altruism and Compassion, between Scientists, Economists, and The Dalai Lama. New York: Picador. 137-145.

Kartasasmita, G. (1997a). "Membangun Ekonomi Pancasila." Naskah disampaikan pada Rakernas AMPI. Jakarta, 26 agustus 1997.

Kartasasmita, G. (1997b). "Peran Pelaku Ekonomi dalam Sistem Ekonomi Pancasila." Naskah disampaikan pada Rapat Kerja BP7 Pusat. Jakarta, 3 Desember 1997.

Kellehear, A. (1993). The Unobtrusive Researcher: A Guide to Methods. St. Leonards, NSW: Allen \& Unwin. Hlm.

Lee, R.M. (2000). Unobtrusive Methods in Social Research. Buckingham, UK: Open University Press.

Mind \& Life Institute (https://www.mindandlife.org/)

Mubyarto. (1996). "Ideologi Pancasila dalam Kehidupan Ekonomi." Dalam Oetojo Oesman \& Alfian (Eds.) Pancasila sebagai Ideologi dalam Berbagai Bidang Kehidupan Bermasyarakat, Berbangsa, dan Bernegara. BP-7 Pusat. Jakarta. 239-248.

Mubyarto. (2000). Membangun Sistem Ekonomi. Yogyakarta: BPFE.

Mubyarto. (2003). Menuju Sistem Ekonomi Pancasila: Reformasi atau Revolusi. PUSTEP-UGM. 7 Oktober 2003.

Mubyarto. (2004a). Bagaimana Belajar Ilmu Ekonomi. PUSTEP-UGM. 6 Juli 2004.

Mubyarto. (2004b). Antara Krisis Ekonomi dan Krisis Ilmu Ekonomi. PUSTEPUGM. 3 Agustus 2004.

Mubyarto. (2004c). Ekonomi Pancasila: Dua Tahun PUSTEP-UGM. PUSTEPUGM. 7 Desember 2004.

Mubyarto. (2005). Lahirnya Ekonomi Pancasila. PUSTEP-UGM. 5 April 2005.

Mubyarto \& Santosa, A. (2004). Pendidikan Ekonomi Alternatif di Sekolahsekolah Lanjutan. PUSTEP-UGM. 3 Februari 2004.

Nugroho, T. (2010a). "Mubyarto dan Ilmu Ekonomi yang Membumi." Dalam E. Soetarto (Ed.) Pemikiran Agraria Bulak Sumur: Telaah Awal atas Pemikiran Sartono Kartodirdjo, Masri Singarimbun, dan Mubyarto, Bab IV "Mubyarto dan Ilmu Ekonomi yang Membumi." (Yogyakarta: STPN Press \& Sajogyo Institute, 2010). 199-321.

Nugroho, T. (2010b). Ekonomi Pancasila: Refleksi setelah Tiga Dekade. 
http://www.academia.edu/1500041/Ekonomi_Pancasila_Refleksi_setelah Tiga_Dekade.

O’Brien, M. (2011). Unobtrusive Research Methods - An Interpretative Essay. http://www.michelleobrien.net/wp-content/uploads/2011/10/ Michelle_OBrien_Unobtrusive_Research_Methods.pdf.

Rahardjo, D. (2004). Ekonomi Pancasila dalam Tinjauan Filsafat Ilmu. PUSTEPUGM, 6 Januari 2004. http://www.ekonomikerakyatan.ugm.ac.id/My\%20Web/sembul12_2.htm

Rahardjo, D. (2008). "Paradigma Pembangunan di Persimpangan Jalan." Makalah disampaikan pada Seminar "Konvergensi Nasional untuk Kemandirian Pangan dan Energi Menuju Kedaultan Bangsa." Dies Natalis IPB ke-45. Bogor, 30 Oktober 2008.

Salim, E. (1965a). Sistem Ekonomi dan Ekonomi Indonesia. Jakarta: LeknasMIPI.

Salim, E. (1965b). "Politik dan Ekonomi Pantjasila". Dalam Widjojo Nitisastro, dkk., Masalah-masalah Ekonomi dan Faktor-faktor IPOLSOS. Jakarta: Lembaga Ekonomi dan Kemasyarakatan Nasional, 1965), 81-97.

Salim, E. (1966). "Sistem Ekonomi Pancasila", dalam Harian Kompas, 30 Juni 1966.

Salim, E. (1979). "Sistem Ekonomi Pancasila", dimuat dalam Jurnal Prisma, No. 5/VIII/1979, 3-9.

Singer, T., Richard, M. \& Hangartner, D. (2015). "Introduction Toward a Caring Economics." Dalam T. Singer \& M. Richard (Eds.) Caring Economics: Conversation on Altruism and Compassion, between Scientists, Economists, and The Dalai Lama. New York: Picador. 1-11.

Singer, T. \& Richard, M. (2015). Caring Economics: Conversation on Altruism and Compassion, between Scientists, Economists, and The Dalai Lama. New York: Picador.

Swasono, S.E. (2009). "Keparipurnaan Ekonomi Pancasila: Menegakkan Ekonomi Pancasila." Naskah disampaikan dalam Konggres Pancasila, bekerjasama dengan UGM \& Mahkamah Konstitusi, Yogyakarta, 30 Mei 1 Juni 2009.

Swasono, S.E. (2010). Indonesia dan Doktrin Kesejahteraan Sosial - dari Klasikal dan Neoklasikal sampai ke The End of Laissez-Faire. Jakarta: Perkumpulan Pra Karsa.

Swasono, S.E. (2012a). "Sistem Ekonomi dan Ekonomi Kontemporer." Penutup Kuliah Penyegaran untuk Dosen dan Mahasiswa S3 Pascasarjana UNS, Solo, 14 Januari 2012.

Swasono, S.E. (2012b). "Meluruskan Penyelewengan Mandat Konstitusi: Pancasila Nasionalisme Pasal 33 UUD 1945 Menolak Neoliberalisme." Kuliah Umum Universitas Negeri Malang, 4 Juli 2012.

Tronto, J.C. (1993). Moral Boundaries. A Political Argument for an Ethic of Care. New York: Routledge.

UUD 1945, Amandemen Ke-4, Jakarta, 10 Agustus 2002.

Van Osch, T. (2013). Towards a Caring Economic Approach. Netherland. May 2013. https://editorialexpress.com/cgi-bin/conference/download.cgi?db name=IAFFE15\&paper_id=354 
Van Staveren, I. (2001). The Values of Economics: An Aristotelian Perspective. London: Routledge - Taylor \& Francis Group.

Witjaksono, M. (2009a). "Ekonomi yang Dipelajari dan Diajarkan, Perlukah Reformasi?" Makalah disampaikan dalam Seminar Pengembangan Kurikulum Pendidikan Ekonomi Program Studi S2 dan S3 di FE UM. Fakultas Ekonomi, Universitas Negeri Malang, 31 Januari 2009.

Witjaksono, M. (2009b). "Reorientasi \& Revitalisasi Pendidikan Ekonomi dalam Konteks Pembangunan Ekonomi Nasional." Pidato Ilmiah disampaikan pada Wisuda Sarjana Semester Genap 2008/2009, STKIP Lumajang, 1 Juli 2009.

Witjaksono, M. (2013). Redefinisi, Reorientasi, dan Redesain Pembelajaran Ekonomi Mengacu pada Amandemen Pasal 33 UUD 1945. Jurnal Pendidikan Ekonomi, 6(1), 1-12.

Witjaksono, M. (2014). "Kontekstualisasi Ekonomi \& Pendidikan Ekonomi di Indonesia." Presentasi pada Seminar Nasional "Pluralisme dalam Ekonomi dan Pendidikan." Jurusan Ekonomi Pembangunan, Fakultas Ekonomi, Universitas Negeri Malang. 29 November 2014. (http://ekp.fe.um.ac.id/?page_id=1104)

Witjaksono, M. (2015). "The Unfinished Agendas: From Pluralism Economics to Contextualizing Economics." Presentation of the 2015 International Conference on Reorienting Economics \& Business in the Context of National and Global Development. Faculty of Economics, State University of Malang, June 13, 2015. (http://ekp.fe.um.ac.id/?page_id=1136)

Witjaksono, M. (2016). “Caring Economics: Konsep, Prinsip, dan Implikasinya bagi Pendidikan Ekonomi di Indonesia." Presentasi pada Seminar Nasional Pendidikan Ekonomi "Membangun Caring Economic Melalui Pendidikan." NCEE 2016 - Pascasarjana Universitas Negeri Malang, 27 Agustus 2016. http://pasca.um.ac.id/ncee2016/. 